\title{
Do formula-based intergovernmental transfer mechanisms eliminate politically motivated targeting? Evidence from Ghana
}

\author{
Afua Branoah Banful ${ }^{1}$
}

\begin{abstract}
Empirical evidence from across the world consistently confirms the pervasiveness of politically motivated targeting of intergovernmental transfers. Some countries have adopted formulaic sharing mechanisms as a strategy to limit political incentives in central resource allocation decisions. The prevailing presumption is that intergovernmental transfers determined by a formula comprising of economic and welfare indicators will obstruct political considerations that distort allocations resulting from processes based on discretion. In this paper, we investigate a formula-based system of allocating resources from a central government to local governments to determine whether the political characteristics of recipient areas have any bearing on their allocation. Specifically, we study the sharing of resources of the District Assemblies Common Fund (DACF) in Ghana amongst the country's district governments over the period 1994 to 2005. We find evidence that the mechanism does not eliminate politically motivated targeting of grants. Per capita DACF grants were higher in districts where vote margins in the previous presidential election were lower, suggesting that districts with more swing voters were targeted. We find evidence that DACF formula indicators and their weighting were chosen and amended to produce politically desired patterns of transfers.
\end{abstract}

JEL classification: $\mathrm{H} 5 ; \mathrm{H} 7$

Keywords: Intergovernmental transfers; Political economy; resource sharing formula

\section{INTRODUCTION}

\footnotetext{
${ }^{1}$ Present address: Development Strategy and Governance Division, International Food Policy Research Institute, 2033 K Street NW, Washington DC, 20006, United States. a.b.banful@cgiar.org. Tel 202-862-5688
} 
Theories of fiscal federalism (Buchanan, 1950; Samuelson, 1954; Musgrave, 1959;

Oates, 1972, 1991, 1997, 1999) imply that determination of intergovernmental transfers based on the political incentives of the allocating entity results in inefficient allocation of resources across geographic regions. Such policies also elicit negative social consequences between classes, ethnic and religious groups which are typically geographically concentrated. However, the range of countries from which evidence of politically motivated targeting of intergovernmental transfers emerges varies from Albania (Case, 2001), India (Khemani, 2007; Cole 2009; Arulampalam, Dasgupta, Dhillon and Dutta, 2009), Argentina (Porto and Sanguinetti, 2001) Portugal (Pereira, 1996; Veiga and Pinho, 2007), Australia (Worthington and Dollery, 1998), Sweden (Dahlberg and Johansson, 2002) and the United states (Wright, 1974; Wallis, 1997, 1998; Anderson and Tollison, 1991; Grossman, 1994).

In the developing world where there is ubiquitous need for development resources, it is especially difficult to determine when central government transfers are influenced by political considerations. Moreover, evidence of ruling governments targeting certain public goods to areas with certain political characteristics does not necessarily signify unfair advantage for these areas. $^{2}$ Nevertheless, in the young democracies in Africa in particular, there is a belief perpetuated by a history of overt political patronage that resource allocation is strongly influenced by the nature of the political relationship the receiving group has with higher tiers of government. ${ }^{3}$ When there is data available, the salience of political considerations in government transfers on the continent is evident. Barkan and Chege (1989) found that in 1980s

\footnotetext{
${ }^{2}$ Mitigating factors include an attempt to counteract interregional inequality and the possibility of regional differences in preferences for different types of public goods as discussed by Alesina, Baqir, and Easterly (1999).

${ }^{3}$ In a striking example of the visible benefits for an area to be politically affiliated with a ruling government, Cote D'Ivoire's President Houphouët-Boigny moved the capital of the country from Abidjan to his political base and hometown Yamoussoukro in 1983; a process which required sponsoring the former agricultural town's rapid growth into a capital city.
} 
Kenya, budget allocations for construction of new roads and health facilities in President Arap Moi's political strongholds of the Rift Valley and Western provinces were disproportionately high. From 1984 to 1988, between 57\% and 68\% of the road budget each year went to these areas which held only 33\% of the country's population. Miguel and Zaidi (2003) showed that in Ghana, annual central government per student expenditure on education in 1998 was $27 \%$ higher in districts that had voted overwhelmingly for the ruling party in parliamentary elections than in other districts.

Various countries around the world have made efforts to mitigate the role of politics in intergovernmental transfers. One strategy has been to place the mandate for distributing national resources with independent agencies. The Finance Commission in India for instance has been shown to have apparent success in removing political bias of receiving regions as an important consideration in their total resource allocation. Khemani (2007) compares the partisan influence in transfers made by a political body, the Planning Commission, with that in transfers determined by the independent Finance Commission. The finding is that resources from the political body are distributed such that Indian states with the same political affiliation as the national government receive greater amounts; especially those states where the party controls only a small proportion of seats in the national legislature. On the other hand, the distribution of resources from the Finance Commission counteracts the advantages of states that are politically aligned with the national government resulting in no partisan impact in the sum of the two sets of transfers.

As another strategy to limit politicians' discretion over intergovernmental transfers, some governments have employed formula-based resource allocation mechanisms. This strategy has gained prominence in the developing world after the wave of decentralization in the last two 
decades. In 1994, Ghana created a pioneering formula-based system of resource allocation through the District Assemblies Common Fund (DACF) that provides the financial sustenance for the local governments of the country. In India, the largest rural development expenditure program, the Sampoorna Grameen Rozgar Yojana (SGRY) launched in 2001, and the 2005 National Rural Employment Guarantee Act (NREGA) that superseded it, are required to devolve resources by means of a formula. South Africa's Local Government Equitable Share established in 1997, Kenya's Local Authority Transfer Fund established in 1999 and Nigeria's Federation Account created in 1999 also use formulas to allocate resources.

The prevailing presumption is that distributing resources by a formula based on economic and welfare variables, will suspend the arbitrariness that allows politically motivated targeting. However, few studies have rigorously tested whether such systems eliminate political considerations from resource allocations. This paper examines the effectiveness of formulas as a strategy for limiting political motivations behind resource sharing by studying whether and how a district's transfers from the DACF over the period 1994 to 2005 were influenced by its political characteristics. DACF transfers are an important medium through which voters perceive the benefits of having a particular political party in office at the central level, thereby giving politicians incentives to manipulate districts' allocations. It is critical that the formulabased strategies for making such important transfers are performing as is presumed.

The DACF is especially appropriate for this study as memoranda and reports available allow us to assemble a uniquely detailed time series dataset of allocations and actual disbursements resulting from a formula-based allocation system. Transfers from the fund constitute the largest source of financing for local government in Ghana and any political bias in the allocations is unlikely to be offset by other government grants. Furthermore, the peaceful 
political environment that has existed in Ghana since the inception of the program precludes the influence of any extraordinary political or economic considerations which could legitimately influence the sharing of the fund. Examining the influence of politics on DACF transfers can provide insights into the scope of political considerations in allocations that result from other formula-based programs.

There is a debate in the theory about the direction in which transfers will be affected based on the political characteristics of the recipient groups. Lindbeck and Weibull (1993) as well as Dixit and Londregan (1996, 1998) model voters as having preferences for particular political parties which they are willing to compromise in response to economic benefits. We refer to models with these assumptions and implications as 'swing voter' models as the empirically expected evidence of political influence in resource allocation is that transfers will be targeted to districts with relatively more 'swing voters'. In contrast, Cox and McCubbins (1986) present what we describe as a 'core supporter' model in which they argue that voters respond more strongly to economic incentives provided by the political party they prefer. Their prediction is that politicians like risk-averse investors will target more resources to areas in which their political support is concentrated in order to have an assured return in terms of votes.

The empirical evidence of which political characteristics are most salient, and in which direction intergovernmental transfers have been affected, are also varied. Similar to the finding that governments targeted more resources to their core supporters as in Barkan and Chege (1989) and Miguel and Zaidi (2003), Case (2001) found that block grants to districts in Albania increased with the president's vote share in the previous election. On the other hand, Cole (2009) finds that Indian state governments supplied more subsidized agricultural loans in election years to districts in which they had a narrow margin of victory or loss suggesting that 
swing voters were targeted. Dahlberg and Johansson (2002) determine that municipalities with swing voters were favored in the award of temporary grants in Sweden, using estimated distributions of political party preference, as well as the vote margin between the two political blocs in the last election as the relevant political characteristics. Using the same data and the vote share of the ruling party in elections and the dummy variable for ruling party majority in the municipal councils as the measures of ruling party support, they did not find support for the 'core-supporter' models.

The empirical analysis in this paper is guided by a working framework based on the 'swing voter' models. However, we also consider empirical specifications that test the hypothesis that incumbent parties target resources to their own supporters. Despite being determined by a uniformly applied formula, we find evidence of political incentives in the determination of DACF allocations and disbursements to districts. In agreement with the prediction of the 'swing voter' models, we found that districts with lower vote margins between the two dominant political parties in the previous presidential election receive higher DACF allocations and disbursements. This suggests that the DACF transfers were targeted to swing voters. We do not find evidence that DACF transfers are targeted to the incumbent's core supporters.

The evidence that a district's formula-based allocation is influenced by its political characteristics implies that the formula itself results in the politically desired pattern of transfers. Statutorily, the DACF formula is chosen by a fund Administrator and voted into law by parliament. However, the administrator is appointed by the president and as such his incentives are presumably aligned with that of the president. The president through the Administrator has informal agenda-setting powers over the formula recommended to the parliament as well as the 
ability to reward or punish parliamentarians based on their votes. Within this structure, the president can advance a formula that produces allocations that are in line with his targeting goals. The DACF formula was changed in each of the years under study except in 1995 . Using the formula from the previous year, counterfactual allocations, the district's allocation had the formula not been changed, were calculated and compared to actual allocations. We find that the formula changes tended to benefit districts that had lower vote margins in the previous elections.

The evidence is consistent with governments being able to achieve sophisticated political targeting even within the confines of the sharing rules of the DACF. It shows that resource allocation by means of a uniformly applied formula grounded in economic variables does not necessarily prevent politically motivated targeting. The structures of a formula based-system, such as who determines the formula, and how and when the formula can be altered, are important determinants of how well it works to prevent political manipulation.

In the next section, we describe the political context and local government structure in Ghana and provide some details of the DACF program. Section 3 presents a working framework of redistributive politics within a two party political environment that is an approximation of the situation in Ghana. The data used in the analysis is presented in section 4. The empirical analysis and a discussion of the results are presented in Section 5. This section also discusses some of the endogeneity and interpretation issues of concern in the analysis. A summary and conclusion is presented in Section 6.

\section{POLITICAL CONTEXT OF THE DACF}

\subsection{Political competition and local government structure in Ghana}


Ghana has been a constitutional presidential republic since 1992. Elections are held every four years in late November when a president is elected by majority rule (50\% plus one vote) for a term of four years. Members of the unicameral legislature, the Parliament of Ghana, are elected concurrently for four year terms. ${ }^{4}$ Since the return to a democratic rule, two parties have dominated politics in the country. The National Democratic Congress (NDC) was founded by Jerry John Rawlings, the military ruler at the time of democratization, who stood for and won the Presidency on the party ticket in 1992 and 1996. The other party is the New Patriotic Party (NPP) whose candidate won the presidential elections in 2000 and 2004. The party ideologies are not very distinct but the NDC is perceived to have a more center-left bias than the NPP. Given these two dominant parties, the actual rule for the election of a president is typically equivalent to a pure majority in a two party system. ${ }^{5}$ In each of the presidential and parliamentary elections that have been held since 1992, either the NPP or the NDC has won both the presidential and the parliamentary election in $95 \%$ or higher of the districts. The party of the president has also always held the majority of seats in the parliament.

The history of local government in Ghana is deeply intertwined with the political history of the country. The government of the first administration, that of Kwame Nkrumah, the leader Ghana's independence movement, dismantled all structures of local government as part of the measures to outlaw all political activity. Nkrumah's government was overthrown in 1966 setting a precedent for eight successive coup d'états in the following fifteen years. The last one in December 1981 ushered into power the military government which ruled the country until 1992.

\footnotetext{
${ }^{4}$ The Parliament of Ghana consists of one Member of Parliament (MP) from each of 230 constituencies.

${ }^{5}$ In 1992, 1996, 2000 and 2004 presidential elections, the NDC and NPP accounted for 85\%, 95\%, 91\% and 95\% respectively of the national votes. With the exception of 2000 when the NPP won only $47 \%$ of national votes in the first round, there has been no need for a second round of voting for one of these parties to achieve the required majority.
} 
Until that military government established the present system in 1988, local government had not existed in any sense as a different entity from central government since the early 1960s.

The local government system in Ghana is multi-tiered and in 2007 comprised of ten Regional Coordinating Councils at the top level, three Metropolitan Assemblies, eleven Municipal Assemblies and 124 District Assemblies at the second level. ${ }^{6}$ I refer collectively to all the types of assemblies as District Assemblies (DAs) as the nomenclature mainly denotes the population under the assembly's jurisdiction. ${ }^{7}$ Each Assembly's area of authority typically comprises one or two constituencies, sub-district administrative areas which are constructs of the legislative arm of government. The duties of the DAs include all "deliberative, legislative and executive functions" of government within the district. ${ }^{8}$ Its activities are divided into the thematic areas of "private sector development"; "human resource development", and "good governance". ${ }^{9}$ Activities under these themes and related subthemes broadly describe all aspects of development in the district including planning, budgeting and provision of public goods, and the promotion of productive activity. The DAs are the rating authority for their jurisdiction and charge licensing fees as well as fees for some services they provide. In essence, the substantive portion of government activities that impacts citizen's consumption of goods and services is carried out by the DA. The Regional Coordinating Councils are mainly responsible for

\footnotetext{
${ }^{6}$ When the system was created in 1988, there were three metropolitan assemblies, four municipal assemblies and 103 district assemblies.

${ }^{7}$ A District has a minimum population of 75,000 people, a Municipality has a minimum of 95,000 people and a Metropolis has a minimum of 250,000 people.

${ }^{8}$ The $462^{\text {nd }}$ Act of the parliament of the Republic of Ghana, The local Government Act, (1993). Section 10, Functions of District Assemblies

${ }^{9}$ Thematic areas deduced from language in the annual reports of District Assemblies. Subthemes for Private sector competitiveness are; promoting trade and industry, employment generation and improvement and expansion of safety nets, support for interventions; development information and communication technology. Subthemes for Human Resource development include; education; training and skills; health; safe water and environmental sanitation; mainstreaming the vulnerable and the excluded. Subthemes for good governance and civic responsibility are; decentralization, political governance; economic governance
} 
coordinating budget proposals and monitoring districts in the region. The sub-district tiers only serve as means for disseminating information from the DAs to the general public and vice versa. Each DA consists of a District Chief Executive (DCE), the members of parliament representing constituencies within the district, elected and appointed assembly members. ${ }^{10}$ Each DCE, the highest office within the district assembly structure, is appointed by the President of Ghana. The Assembly functions through a committee system in which final decisions on the proposals and initiatives of sub-committees are made by an executive committee. ${ }^{11}$ Elections to the DAs are held on non-partisan bases once every four years but occur two years after presidential and parliamentary elections. In reality, informal party activity plays a major role in the elections.

\subsection{Overview of The District Assemblies Common Fund}

During the first few years of their existence, the financial resources of the DAs, consisting of their locally raised revenue, were meager and virtually all of their mandated responsibilities continued to be fulfilled by the central government. To bolster the local government system, the 1992 Constitution of the Republic of Ghana required the establishment of a "District Assemblies Common Fund" from which grants are to be disbursed to DAs according to a formula. ${ }^{12}$ The sharing formula for the DACF endowment is determined annually by the head of the DACF office, the Administrator who is appointed by the President for

\footnotetext{
${ }^{10}$ The local government law states that no less than $30 \%$ of the members of the DA must also be appointed by the president.

${ }^{11}$ Each District Assembly has at least the following sub-committees reporting to an Executive committee; Development and Planning, Social Services, Works, Justice and Security, Finance and Administration.

${ }^{12}$ The Constitution of the Republic of Ghana, Article 252
} 
renewable terms of four years and is a de-facto political appointee. ${ }^{13}$ The first DACF formula was presented to parliament in March 1994 and disbursements to districts began shortly after.

The Ghanaian Constitution states that parliament must approve the DACF formula by a majority vote. In practice, the Administrator submits the proposed formula and resulting DACF shares of the various districts to the office of the President prior to making a recommendation to parliament. The sharing formula submitted to parliament by the Administrator has always been approved without change. As such, the ruling party, through the President, has direct influence on the final DACF formula.

The DACF is the most important source of revenue for DAs and between 1994 and 2005, grants from the program constituted on average $80 \%$ of an assembly's annual expenditure. While there are broad guidelines which tie the use of the DACF funds to the thematic areas in which the assemblies activities are grouped, in theory, DAs are free to use the funds as they wish as long as the intended use is in the budgets furnished to the DACF Administrator prior to disbursements. However, a common complaint by DAs is lack of total discretion over how to use their allocated funds.

The total endowment of the fund is determined annually by Ghana's Parliament and by law cannot be less than $5 \%$ of the total revenues of Ghana. A later Act in 1993 defined total revenues of Ghana as: "All revenue collected by or accruing to the central government other than foreign loans, grants, non-tax revenue and revenues already collected by or for DAs under any enactment in force."14 This Act limits the statutory size of the DACF endowment but the fund is

\footnotetext{
${ }^{13}$ The first DACF Administrator was appointed in 1993 by President Jerry John Rawlings of the National Democratic Congress (NDC) political party. That Administrator was replaced in 2001 at the beginning of the Presidency of John Agyekum Kufour of the rival New Patriotic Party (NPP).

14 The District Assemblies Common Fund Act 1993 (act 455)
} 
still significant nationally: it typically constitutes about $25 \%$ of the central government's total domestic development budget in a year.

The DACF formula has changed almost annually since 1994 but the same three overarching categories have been used in calculating districts' shares. These categories are denoted as "NEED", "RESPONSIVENESS" and "SERVICE PRESSURE". Each category is comprised of several indicators that are transformed by various functions. A district's share of the DACF endowment is calculated as a weighted linear combination of these transformations and is increasing in some indicators and decreasing in others. Table 1 shows the indicators that comprised each of the formula categories and the respective weights attached to their transformations for the years 1994 to 2005. The functions used in the formula are shown in the Appendix.

\section{Insert Table 1}

While the broad categories of variables used in the formula have not changed, the compositions of the categories and their weighting have changed each year. The DACF formula proposals for the various years state that "NEED" category is included to measure a district's lack of services relative to other districts in the country. This category has seen the most changes in its composition. In 1994, the "NEED" of the district was measured with transformations of its 1992 GDP per capita and population. In 1996, population was dropped and number of health facilities and basic education facilities were considered. In 2000 further refinements were made to the category, by dropping the 1992 GDP per capita and including population per doctor and pupils per teacher as measures. In 2002, the percentage of the district supplied with safe 
drinking water was considered and in 2004, mileage of tarred roads in the district was also added as an indicator.

The DACF formula proposals state that the "RESPONSIVENESS" category is incorporated in the formula to motivate districts to generate local revenue and is comprised of measures that are believed to reflect the DA's efforts in that regard. Up to 1995, the sole variable used in this measure was the level of locally raised revenue per capita. From 1996 to 2001, increase in locally generated revenue per capita was added to the category. In 2002, the level of locally raised revenue per capita was dropped from the category. Between 2003 and 2005, the "RESPONSIVENESS" of a district was measured by a transformation of only one new variable; the increase in locally raised revenue. The "SERVICE PRESSURE" category is described in the formula proposals as a measure of the intensity of use of public facilities in a district. It has comprised solely of the population density of the district since the inception of the DACF. In 2003, there was a one-time inclusion of a "POVERTY" category in the DACF formula. This category was comprised of the proportion of schools in the district that were dilapidated.

In addition to the three categories in the formula, an item labeled "EQUALITY" stipulates which percentage of the DACF allocation is to be distributed evenly between the districts. This provision assures every district a certain proportion of the DACF endowment. The "EQUALITY" item was increased dramatically in 2004 to $60 \%$ from about $30 \%$ in all the previous years. Before the DACF endowment is shared according to the formula, an amount referred to as "CONTINGENCY" from 1994 to 1999 and later renamed the "RESERVE" is subtracted. This amount was $5 \%$ of the endowment in 1994, $10 \%$ from 1995 to $2004,20 \%$ in 2005 and $25 \%$ in 2006. The DACF office reports that this "RESERVE" amount is used for bulk 
purchases for the DAs and to support the Regional Coordinating Councils and the office of the DACF Administrator in their monitoring roles. Also, a proportion of the "RESERVE" is distributed evenly between all the members of parliament for development projects of their choosing in their constituencies.

The choice of indicators and their weighting in the DACF formula has changed unpredictably over time and it is apparent that districts have essentially no capacity to increase their future allocations by changing their level of any particular indicator. Furthermore, because the formula utilizes a comparison of the indicator in a district with the level of the indicator in all others, a district requires information about the strategies of all other districts in order to predict how a change in its own level of a particular indicator can affect its share of the DACF. Also, since the data used in the formula is only available from the relevant sector ministry after a two or three year lag, districts cannot anticipate when and whether any actions they take to affect their level of a formula indicator will be relevant. The unpredictability of which indicator will be relevant is especially important for the "RESPONSIVENESS" category which is explicitly included in the formula to encourage local revenue generation and should comprise of a steady indicator that districts can respond to.

\subsection{ANALYTICAL FRAMEWORK}

To determine the presence and nature of any politically motivated targeting of DACF resources, we use a working framework that captures the salient characteristics of the DACF, local government structure and the political background in Ghana. This framework draws heavily on the models of redistributive politics by Dixit and Londregan $(1995,1996)$. 
Consider a country consisting of distinct administrative districts labeled from 1 to $\mathrm{N}$ with the subscript $i$ denoting the characteristics of district $i$. The total population of the country is given by $\mathrm{P}=\sum_{i=1}^{N} P_{i}$ where $\mathrm{P}_{i}$ is the population of district $i$. There is a government that has the sole function of making transfers to citizens out of an endowment of size $\mathrm{Y}$ that is exogenously given. All citizens within a district receive the same amount of transfer but the individual transfer amounts may differ across districts. "Government" consists of one president who has agenda setting power on the distribution of $\mathrm{Y}$, and $\mathrm{N}$ members of parliament, one each from each district, who through their legislative votes can accept or reject the proposed distribution of Y.

There are two political parties, Party I which is the party of the incumbent president and Party $\mathrm{C}$ which is the party of the challengers, under whose auspices one candidate each can stand for election for the office of the president or as one of the $\mathrm{N}$ members of parliament. Politicians from both parties want to be in power for the intrinsic benefit of being in power or if they extract rents, they do so at the same rate. The President is elected by winning a national majority in the presidential election and a member of parliament by winning the majority of votes cast in the district in the parliamentary election. Within each party, politicians are identical and if the majority of the votes cast in a district is for the presidential candidate of Party I (Party C), then the elected Member of Parliament for the district is also from Party I (Party C). As such, typically the majority of the members of parliament are from the same political party as the President. There is a party hierarchy through which a President can reward or punish members of parliament who are from his political party.

Let $\left(\mathrm{G}_{\mathrm{iI}} ; i=1,2,3, \ldots \mathrm{N}\right)$ be the amount of the transfer the incumbent government offers to residents of each district and $\left(\mathrm{G}_{\mathrm{iC}} ; i=1,2,3, \ldots \mathrm{N}\right)$ the binding amounts the challenging party 
promises to offer if elected. Both parties have to allocate the same total amount of resources so that $\mathbf{Y}=\Sigma G_{\text {iI }}=\Sigma G_{\text {iC }} \quad(1)$.

For Party I, the sharing of $\mathrm{Y}\left(\mathrm{G}_{\mathrm{ii}} ; i=1,2,3, \ldots \mathrm{N}\right)$ is selected by the President but must be accepted by a majority of sitting parliamentarians. The sharing of $\mathrm{Y}$ promised by Party $\mathrm{C},\left(\mathrm{G}_{\mathrm{iC}} ; i\right.$ $=1,2,3, \ldots . \mathrm{N})$, is selected by the Presidential candidate for the Party.

Voters differ in their intrinsic preference for Party I over Party C and even within districts voters are heterogeneous in their affinities for the two parties. These differences are derived from things such as party identity and personal attributes of the candidates. However, voters are rational and self interested individuals and in addition to the benefit they derive from having their favored political party in power, they care about their private consumption and are willing to trade off their political preferences in return for economic benefits. The utility of a voter in district $i$ is given by $\mathrm{U}_{i}\left(\mathrm{y}_{i}+\mathrm{G}_{i}\right)$ where $\mathrm{y}_{i}$ is the income of a voter in district $i, \mathrm{G}_{\mathrm{i}}$ is the transfer is received and $\mathrm{U}_{i}$ is a utility function such that $\mathrm{U}_{i}^{\prime}>0$ and $\mathrm{U}_{i}<0$. Following Dixit and Londregan (1996) voters are modeled as a continuum distributed along the real numbers where a voter located at X has a preference for Party I over Party C. A voter in district i, with the preference $\mathrm{X}$ for Party I will vote for Party C if

\section{$\mathbf{U}_{i}\left(\mathbf{y i}+\mathbf{G}_{i C}\right)-\mathbf{U}_{i}\left(\mathbf{y i}+\mathbf{G}_{i i}\right)>\mathbf{X}$}

The critical value or "cut point" for district $i$ whereby all citizens of district $i$ with values of $X$ less than $\mathrm{X}_{i}$ will vote for Party $\mathrm{C}$ and all the rest for Party I is given by

$$
\mathbf{X i}=\mathbf{U}_{i}\left(\mathbf{y i}+\mathbf{G}_{i C}\right)-\mathbf{U}_{i}\left(\mathbf{y i}+\mathbf{G}_{i l}\right)
$$


Letting $\Phi_{i}\left(\mathrm{X}_{i}\right)$ represent the proportion of the population in district $\mathrm{i}$ to the left of $\mathrm{X}_{\mathrm{i}}$ the total vote that Party $\mathrm{C}$ receives in the Presidential election is

$\mathrm{VP}_{\mathbf{C}}=\sum_{i=1}^{N} \boldsymbol{P}_{\boldsymbol{i}} \Phi_{\boldsymbol{i}}\left(\mathbf{X}_{\boldsymbol{i}}\right)$

and

$\operatorname{VMP}_{\mathbf{C}}=\mathbf{P}_{i} \Phi_{i}\left(\mathbf{X}_{i}\right)$

is the number of votes Party $\mathrm{C}$ receives in the parliamentary election in district $\mathrm{i}$. The total votes the presidential candidate for Party I receives is

$\mathrm{VP}_{\mathrm{I}}=\sum_{i=1}^{N} P_{i}-\mathbf{V}_{\mathrm{C}}$

and

$\mathrm{VMP}_{\mathrm{I}}=\mathbf{P}_{i}-\mathbf{P}_{i} \Phi_{i}\left(\mathbf{X}_{i}\right)$

is the number of votes Party I receives in the parliamentary election in district $i$.

As is evident in equations 4, 5, 6 and 7, the outcome of both the presidential and parliamentary elections depends on the amount of transfers both parties promise each district. The strategic distribution of $\mathrm{Y}$ that both parties promise is however determined solely by maximizing equations 4 and 6 given the budget constraint i.e., the presidential election vote maximization problem. The incumbent president can push through the transfers that maximize his vote using his party majority in parliament even without consideration for the reelection prospects of individual members of parliament from his party. In districts in which the distribution does not maximize the votes in the parliamentary election for a candidate from his party, the president is assured of a "yes" vote because of his ability to punish or reward the parliamentarian through the party structure. The presidential candidate of Party $\mathrm{C}$ can also promise a sharing of the endowment that considers only his vote maximization problem because 
other politicians in his party standing for parliamentary elections face the threat of punishment should he become the president.

In the Nash equilibrium strategy of the transfer allocations of both parties, which districts will be targeted for higher transfers? An immediate intuition for how a vote maximizing presidential candidate will allocate vote-buying resources is that he will target areas with larger populations. However, in the first order conditions of maximizing of $\mathrm{VP}_{\mathrm{C}}$ and $\mathrm{VP}_{I}$ subject to the respective budget constraints, district population cancels out. The intuition presented by Dixit and Londregan $(1995,1996)$, is that while larger districts have more voters, they also require more funds in total which offsets the effect of total votes gained by shifting resources to them. The amount of $\mathrm{Y}$ each district receives (is promised) is instead increasing in the willingness of the district's voters to trade off their preferences for a particular political party in response to economic benefits, and the density of the districts population at the 'cut point' of the district. Both parties will target less of the endowment to districts with population distributions in which most citizens strongly prefer one party over the other. The party that is favored will gain more by using the additional funds it would have given to that district to target another district where it can switch votes to its favor. The other party will gain little by taking funds from an area where it has more of the population amenable to supporting it and transferring it to that district.

If the distribution of party preferences $\mathrm{X}$ within a district is symmetric and single-peaked, the 'cut point' density is negatively correlated to the difference in vote shares of the two parties in the presidential elections. With this assumption, the vote margin can be used to proxy for the 'cut point' density in empirical specifications. The vote margin is also positively correlated with the proportion of swing voters, the population that can be easily swayed by transfers to support 
one party or the other, in the district. The implication of the framework is therefore that in the equilibrium set of DACF transfers, districts with more swing voters will receive higher transfers.

This framework represents an accurate approximation of the setting within which Ghana's DACF operates. It reflects that the DACF funds are targeted and typically benefit only residents of the particular district in the form of provision of goods and services which have some private consumption component. From the point of view of the citizens, the DACF endowment is exogenous as they are neither directly taxed, nor can they vote on the size of the endowment. The DACF administrator is appointed by the president and has no incentive to deviate from the president's wishes. He is in some terms, a skilled technician hired by the president to produce a sharing formula that maximizes the chances of election for a presidential candidate from his party. It is therefore reasonable to approximate that the president sets the sharing of the DACF endowment, albeit indirectly. The president has agenda setting or bargaining power (through the administrator) with the members of parliament because statutorily, parliamentarians cannot change the DACF formula but only accept or reject it. Considering that the sitting president has influence over ministerial appointments, diplomatic postings, and party campaign funds, the assumption that the President has a mechanism of rewarding or punishing parliamentarians, especially those from this own party is reasonable. Even if the threat of punishment was not severe, parliamentarians may have a general inclination to tow their party line. An interesting fact that is revealed in this framework is that under the structure of the determination of the DACF sharing formula, actors at the district level like the DCE or assembly members, have no direct influence on the amount of the endowment that their district receives. 
Aside from an empirical specification based on the predictions of this working framework, we also consider specifications based on the predictions of a framework informed by the work of Cox and McCubbins (1986). In that framework, district residents respond differently to transfers from the two political parties - the same transfer given by the political party they prefer has a higher impact on their utility. The implication is that candidates give benefits to districts with the highest electoral rates of return and promise lower benefits to those with the lower rates of return. Consequently in terms of the sharing of the DACF endowment, the ruling government will give little to districts where opposition to their party is strong, somewhat more in districts which have not shown a clear preference for one party of the other, and the most in districts which clearly support them.

\section{DATA}

The data used in the empirical analysis is a panel dataset for the years 1994 to 2005. Data relating to the DACF were obtained from internal documents from the headquarters of the DACF in Accra, Ghana. The unit of observation in this dataset is the district and it contains measures of the variables used to calculate the districts' shares of the DACF endowment for each year. The disbursement to each DA is also gathered from annual reports of DACF utilization submitted to parliament after each year. With some exceptions, the following variables are available annually from the years in which they became relevant for the formula: population, number of health facilities, population per doctor, population per nurse, number of elementary schools, pupils per teacher, percentage of district with potable water, and mileage of tarred roads. We confirmed by calculation that the formulae are strictly followed in determining the DACF allocations that are announced to districts. However, the amount of funds actually released to 
districts, DACF disbursements, generally differs from the allocations. The mean of DACF allocations, disbursements, and the coefficient of variation in disbursements in each of the years are shown in Figure 1.

\section{Insert Figure 1}

The ratio of annual disbursement to allocation over the period 1994 to 2005 ranges between 0.91 and 1.53. Throughout the discussion, I make a distinction between districts' DACF disbursement and allocation in order to determine any politically motivated non-random deviations of disbursement from allocation. Both the districts' allocations and disbursements have been growing over time. The average annual DACF disbursement to districts ranges from $\$ 157,609$ to $\$ 2,083,645$ (PPP 2000 US\$). The average ratio of disbursement to allocation has been falling over the years with an unusually low ratio in 2002. The DACF Administrator explained that in 2002, only one quarter of the amounts allocated to districts were disbursed due to "technical and transitional difficulties" with his staff. ${ }^{15}$ The unit-less coefficient of variation shows that the first four years of the DACF program was characterized by highest inequality in the distribution with a sharp reduction beginning in 1998. A summary of the DACF data is shown in Table 2.

\section{Insert Table 2}

Election results for the 1992, 1996, 2000 and 2004 parliamentary and presidential elections were obtained from the headquarters of the Ghana Electoral Commission in Accra, Ghana. The variables in the dataset include the number of registered voters, the voter turnout, the number of valid votes, the political party of each presidential and parliamentary candidate

\footnotetext{
${ }^{15}$ Personal conversation with District Assembly Common Fund Administrator held in August 2006.
} 
and the number of votes each candidate received. The unit of observation for all of these election data is the constituency level but the data was further aggregated to the district level. The list of political parties that contested each election is presented in the Appendix. It shows the political dominance of two parties, the National Democratic Congress (NDC) and the New Patriotic Party (NPP). These two parties have accounted for on average, 84\%, 96\%, 91\% (100\% in the run-off) and 95\% in the 1992, 1996, 2000 and 2004 district level presidential election results respectively. A party is described as winning a district or constituency or in the presidential or parliamentary election if it captures a majority of the votes there. It has almost always been the case that the candidate from the NPP or the NDC wins in both the presidential and the parliamentary election. In my framework, election results in the presidential elections are the ones that should influence DACF sharing. Nevertheless, parliamentary election results are virtually identical to the presidential election results.

The vote margin between the two dominant parties, the NDC and the NPP, in the presidential elections is calculated. In their empirical analysis of tactical use of a temporary grant program to Swedish municipalities, Dahlberg and Johansson (2002) use the vote margin as a proxy for the 'cutpoint' density which they also explicitly calculate using survey results from a voter political ideology preference survey. They find agreement between the vote margin proxy and the calculated 'cutpoint' density in their conclusion that governments target areas with more swing voters. In the absence of political preference data for Ghanaian districts, we rely on the vote margin to serve as a proxy for the district population density at its 'cutpoint'. The margin between the two parties is lower when the election is close and indicates a higher 'cutpoint' population density ${ }^{16}$. For empirical specifications informed by the Cox and McCubbins( 1986)

\footnotetext{
${ }^{16}$ Under the assumption of a single-peaked distribution function of district voters' preferences over one of the two dominant political parties.
} 
framework, the ruling government's vote share and a dummy variable, set to one if the incumbent president won the most votes in the district in the last presidential election, are used to capture a district's support for the ruling party over the opposition party. A summary of the election data is shown in Table 3.

\section{Insert Table 3 here}

\section{EMPIRICAL ANALYSES AND DISCUSSION}

\subsection{Is there evidence of political considerations in the DACF outcomes of districts?}

Due to the public goods provision goals that led to the creation of the DACF, it is possible that systematic developmental differences between the types of areas that support the two political parties can lead to differences in DACF outcomes of districts even in the absence of political manipulation. However, if there is no political consideration in the sharing of the DACF endowment, in a regression model that controls for equity considerations the coefficients on variables capturing the 'cutpoint' density from the working framework of politically motivated sharing, or on measures of government support from the Cox and McCubbins (1986) framework should have statistically insignificant coefficients. If the ruling party targets resources to districts where they get the highest marginal benefit as in the framework, the expected sign on the vote margin in the district presidential elections is negative. If however, the ruling party views sharing DACF resources like a chance to invest in areas with varying electoral returns, a positive and statistically significant coefficient is expected on the vote share of the ruling party in the district in the last presidential election, or the dummy variable of whether the ruling party won the district. 
What variables should be included in a regression model to control for district development needs and the equity goals of the ruling government? Our strategy is to proxy for both of these considerations using measures of district wealth. Income per capita, which is a commonly used measure for wealth, is only available at district level in 1992. The best available time series proxy for district wealth is the number of schools. If more development resources are sent to the poorer districts, this measure of wealth is predicted to have a negative coefficient. However, a negative coefficient on the measure of wealth could also be evidence of tactical distribution of the DACF as citizens of poorer districts are likely to be more responsive to economic benefits.

A fixed effects (FE) estimation model is used to allow an estimate of coefficients on the political affiliation variables of interest, while controlling for unmeasured stable covariates that reflect equity considerations that influence the sharing of the DACF. While this strategy does not fully resolve the argument that the equity considerations can change over time, it is unlikely that relative development needs of districts have changed dramatically over the twelve year period under study.

The regression specifications estimated are full and nested versions of (8):

$\mathrm{y}_{\mathrm{it}}=\beta_{0}+\beta_{1}$ POLTCS $_{\mathrm{it}}+\sum_{t=1994}^{t=2004} \gamma_{\mathrm{t}}\left(\right.$ YEARt $\left._{\mathrm{t}}\right)+\sum_{t=1994}^{t=2004} \varphi_{\mathrm{t}}\left(\right.$ YEARt $_{\mathrm{t}} *$ POLTCS $\left._{\mathrm{it}}\right)+\beta_{3} \mathrm{Z}_{\mathrm{it}}+\mathrm{a}_{\mathrm{i}}+\mathrm{u}_{\mathrm{it}}$

where the dependent variable is either log per capita disbursement or log per capita allocation, POLTCS is one of three variables that capture political considerations: 1) the proxy for 'cutpoint' population density which is the margin of votes between the NPP and the NDC, 2) the vote share of the ruling party, or 3) the dummy variable for a ruling party victory, YEARt is a dummy variable equal to one in year $t$ and $Z_{i t}$ is the proxy for district wealth. YEARt captures 
year specific fixed effects and YEARt interactions with POLTCS are included to allow the nature of the politically motivated targeting to vary from year to year.

The results of the regression in (8) when the dependent variable is log per capita disbursement are shown in Table 4. Columns (1a) and (1b) show the specification from the working framework. The negative and statistically significant coefficients on the vote margin in the district show that districts with larger vote margins in the last presidential elections received a lower per capita transfer from the DACF endowment. This finding provides evidence which suggests that there is a political motivation in the sharing of the DACF endowments and that governments target more resources to districts where the vote of a higher proportion of the population may be influenced by economic benefits. The transfers to residents in a district with average vote margin in 1992, 1996, 2000 and 2004 is $4.6 \%, 4.4 \%, 4.0 \%$ and $3.6 \%$ respectively lower than transfers to a resident in a district in which the two parties received almost $50 \%$ of the vote each $^{17}$. The coefficient on the district wealth measure is negative showing that poorer districts received higher per capita transfers. However, one cannot distinguish if the poorer districts received high transfers due to equity or political considerations.

Columns (2a) to (3b) show specifications informed by the 'core-supporter' models. While the coefficients on the variables capturing ruling government political support in the district are statistically significant, they are negative (except in 1995 and 2003) when the model predicts positive coefficients. These regression results suggest that DACF transfers are made with political considerations, but they provide evidence against governments targeting resources to their constituents as predicted by the model.

\footnotetext{
${ }^{17}$ The average per capita disbursement was \$22 (PPP 2000 US\$) between 1994 and 2000, and \$68 (PPP 2000 US\$) between 2001 and 2005 .
} 
In Table 5, the results of the regression in (8) when the dependent variable is log per capita allocation are shown. It shows that political considerations are present in the allocations that result from the application of the DACF formula. The coefficients in each regression when the dependent variable is district per capita allocation are almost identical to those resulting from a regression of actual per capita disbursement. The evidence corroborates the findings that governments target more resources to districts where they can attract more citizens to vote for their party. The coefficients on measures of ruling government support again have the opposite sign than would result if ruling parties were targeting resources to areas where they perceived strong support. In short, Tables 4 and 5, provide evidence that DACF transfers are not independent of political considerations and that governments have targeted more transfers to districts with high electoral competition.

\subsection{How is politically motivated targeting achieved under a formula based framework?}

A government is somewhat constrained in making transfers to a region when the amount each region receives is based on a formula that is uniformly applied to all areas. However, there politically motivated targeting can still be achieved even within the formula based framework.

One way is to disburse different amounts to the region than it is allocated based on a formula chosen with purely economic considerations. Another way, which is particularly effective if each district is entitled to a certain base amount of transfers as is the case of the DACF in Ghana, is to create more districts in the areas that the government wishes to benefit most. Finally, politically motivated targeting of the resources can be achieved when indicators and weights used in the formula can be chosen so as to result in allocations that have the desired targeting goals. 
There has been one episode of redistricting in Ghana during the period under study. This redistricting took place in 2004, a decade after the inception of the DACF and could not have been the main mode for the achieving the politically motivated targeting of DACF resources observed in the earlier years. Furthermore, as shown in the appendix, the probability that a district was split in 2004 is not correlated to any aspect of its voting history in both presidential and parliamentary elections. ${ }^{18}$ The main consideration for the splitting of districts was apparently the district size and neither the vote margin, nor the measures of ruling government support in the district, nor the proportion of district parliamentary seats won by the ruling government have any explanatory power.

The evidence of political considerations in DACF allocations suggests that the DACF formula itself, and not deviations of disbursement from allocation, was the primary mode through which districts were targeted. This situation is all the more likely as there have been adjustments in the DACF formula each year except in 1995 when the formula from 1994 was maintained. Strikingly, the major changes in the DACF formula all took place in election years, 1996, 2000 and 2004. The formula change in 2002 was considerable, but that year was also significant, as it was the first full year of the DACF under an administrator appointed by a different regime. In view of the creation of the DACF to address the development needs of districts, formula changes may have been legitimately required each year to improve the targeting of DACF based on district economic and welfare considerations. One may for instance find that the formula change resulted in districts with lower wealth receiving a higher allocation than they would have under the previous year's formula. However, the frequent formula changes could also have been for the benefit of the incumbent party's vote maximization.

\footnotetext{
${ }^{18}$ Election results from 1992 are not included in the voting history because opposition political parties deemed the presidential elections so flawed that they boycotted the parliamentary elections.
} 
To provide further evidence that the formula changes were tactical, it is instructive to compare districts' actual allocations in each year, with their allocation had the formula not been changed. If the formula changes were not made to achieve political targeting goals, the ratio of a district's actual allocation to its counter factual allocation should not be correlated with any district political characteristics in a regression controlling for district wealth measures. In following with the finding that governments make higher transfers to districts with more competitive elections, the expectation is that the formula change results in actual allocations being higher than the allocations would have been under the status quo in such districts. If governments use the formula change to invest even more in their areas of strong support, then this ratio of a district's actual allocation to its counter factual allocation will be increasing with the level of support a ruling party perceives in a district.

To provide evidence of political considerations in DACF formula changes, the same arguments for using FE estimation and district wealth controls from the previous section apply. The specification is identical to that in (8) where the dependent variable is log (actual allocation/counter factual allocation). The results of the regressions in this specification are shown in Table 6

\section{Insert Table 6}

As shown in columns (1a) and (1b), the estimated coefficients on the vote margins for the district, are negative in each year, except in 2001 and 2004, when it is zero. This shows that the formula changes have tended to increase the allocation of districts with higher population that can be induced to vote for the ruling party compared to what they would have received without a formula change. While the negative coefficients for each year are not individually statistically 
significant (except in 1997 where it is significant at the 10\% level), they are jointly significant at greater than $1 \%$ level. The magnitude of the decrease in the ratio of actual DACF allocation to the counter factual for every percentage point of vote margin is highest in 1997 and in 2000 where the ratio in a district with the average vote margin is $10 \%$ lower than in places where the vote was split almost evenly. Columns $(2 a)-(3 b)$ provide further evidence of political motivations behind the formula changes. However, the hypothesis that the government changes the formula to target its own areas is rejected in most years. When ruling party vote percentage in a district is used as a measure of government support, the evidence is that the formula changes benefit opposition districts in each year except in 2002. In columns (3a) and (3b) where an alternate measure of ruling party support in the district is considered, the coefficients are again all negative except again in 2002, 2000 and in 1999. With the special significance of the year 2002, the finding that the formula change in that year benefited the incumbent's core supporters is noteworthy. The statistically significant and positive effect of ruling government support on the ratio of actual allocation to counter factual allocation suggests that in that year, the formula change may have indeed been made with consideration for benefiting core supporters of the ruling party.

The negative coefficient on the district wealth in all three specifications suggests that the formula changes on average resulted in poorer districts receiving a higher share than they would have otherwise. While this coefficient is only marginally significant, it provides evidence that the formula changes could have been at least in part motivated by equity considerations. Nevertheless, the evidence that emerges is that the DACF formula is manipulated to achieve politically motivated targeting goals. 


\subsection{Endogeneity and interpretation issues}

The influence of political characteristics of a district on the intergovernmental transfers it receives suffers from potential endogeneity and interpretation problems. An argument could be made that the finding that districts with closer past elections are targeted for higher transfers from the DACF is because such districts also happen to be the ones who should get higher transfers under a distribution pattern that is based on purely economic considerations. However, the concern that genuine district development need correlated with political affiliation drive the results is somewhat abated by the panel nature of the data, controlling for district wealth and the estimation method. The FE coefficient estimates the effect of within-district variation in the particular outcome when its political characteristics change, while controlling for fixed unmeasured district characteristics, even if they are correlated with the political variables of interest. An additional concern would be that the unmeasured district characteristics which could be correlated with the changes in the vote margin of the district are not fixed. However, it is unlikely that, over the 12 year period under study, any unmeasured district characteristics have varied significantly.

The significance of political variables in DACF outcomes of districts makes it clear that political considerations are at play in the sharing of the fund. The remaining issue is whether governments target swing districts or their core supporters with transfers from the fund. However, regression specifications for determining which of these theories best describes reality calls for measures of district political characteristics that are correlated with each other. The measure of swing voter concentration in a district is correlated with measures of the ruling party support in the district. It is then possible, as is shown in this paper, to find political characteristics of the districts being statistically significant in regression specifications guided by 
each of the opposing theories. The determination in this paper that governments target swing districts is made because the empirical results match well with the predictions from a theoretical framework that is a good approximation to the situation in Ghana. One could argue for an alternative interpretation based on the negative and statistically significant coefficients on measures of incumbent support, that government targets opposition districts. However, the alternative interpretation would be direct contrast to the theoretical predictions of the framework that informed the empirical set-up.

Due to the fact that changeable district characteristics are included in the DACF formula, there is possibility of a feedback loop in which districts can affect their future DACF outcomes by altering variables that alter their welfare situation. For this mechanism to result in the observed statistically significant correlations, the ability to know which variables to choose to alter and to actually alter them would have had to be correlated with district political affiliation. This scenario is unlikely to exist as frequent formula changes make it virtually impossible for any district to successfully anticipate a future year's formula.

\section{CONCLUSION}

Empirical evidence from across the world has shown several instances in which intergovernmental transfers are influenced by the political characteristics of receiving regions. In an attempt to limit politically motivated distribution of national resources, some governments have adopted formulaic revenue sharing mechanisms. However, an important unanswered 
question is whether formulas are sufficient to eliminate politically motivated targeting of transfers.

This paper explored whether there was tactical sharing of the resources of the District Assemblies Common Fund (DACF) in Ghana. Unlike other centrally sourced development resources which are determined at the discretion of government agencies, districts' DACF allocation is determined annually by a formula recommended by the DACF Administrator and voted into law by the Parliament of Ghana. With an average of $80 \%$ of the revenue of DAs being derived from the DACF, the transfers from the fund have a noticeable effect on the welfare of citizens at the local level. The DAs are officially non-partisan bodies. However, due to the fact that the head of each assembly and $30 \%$ of assembly persons are presidential appointees, the citizens' experiences of service provision by the DA is linked to their perception of the benefit of having a particular political party in power at the center. This situation creates a role for the DACF transfers as a political tool to boost the election prospects of candidates from the incumbent political party. In the structure of the DACF, the president is well placed to ensure a sharing of the DACF endowment that maximizes his votes in the presidential elections.

We find evidence of politically motivated targeting of DACF transfers despite the formula-based system of sharing the endowment. We find that DACF allocations resulting from the formula, as well as actual disbursements, are higher in districts where past presidential elections have been closer. This finding is in agreement with the predictions of the 'swing voter' models of Lindbeck and Weibull (1993) and, Dixit and Londregan (1996, 1998) in which government target resources to areas where a higher number of voters can be induced to vote for them with economic benefits. We find no evidence to support that the ruling governments target resources to their core-supporters as predicted by Cox and McCubbins (1986). The evidence 
shows that the targeting of DACF resources was achieved by manipulation of the formula itself. Comparing a district's actual allocation to the counter factual allocation had the formula not been changed, we find that the formula changes have tended to increase the allocation of districts with more swing voters. We do not find evidence that the formula changes benefited the incumbent governments' core supporters.

The results of this study show that there is scope for politically motivated targeting even in a formula-based system of allocating transfers. These findings suggest that effectiveness of formula-based systems in curtailing politically motivated targeting requires more than just a formula. In particular, the incentives of the agency or individual setting the formula must be clearly separate from that of any politician's. Furthermore, the ability to arbitrarily change the guiding formula may be an important loop-hole through which incumbent regimes can manipulate allocation. Nevertheless, it is possible that formulas limit the extent to which politics drives resource allocation. With complementary structures to limit political influence over their creation, formula's can form the basis of mechanisms of resource allocation that is purged of political considerations.

\section{Insert Appendix containing Tables 7, 8 and 9}




\section{ACKNOWLEDGEMENTS}

I am grateful to Michael Kremer, Matthias Schündeln and Rohini Pande for suggestions and comments. I thank the Harvard Center for International Development and Warburg Funds for research support. I also thank Xiaobo Zhang, J. Atsu Amegashie, Christian Henning, Janina Matuszeski and participants of the Harvard/MIT Economic Growth and Development Workshop

for helpful comments. I am especially grateful to Fred Tetteh of the Research Division of the Ghana Electoral Commission, Samuel Aidoo and Patrick Zioku of the District Assembly Common Fund Office for sharing data. I would also like to thank, Mr Magnus Nicol the Administrator of the District Assembly Common Fund, Grace Bediako, Ghana Government Statistician, Dr Regina Adutwum, Director General of the National Development Planning Commission and Professors Kwame Boafo-Arthur and Joseph Ayee of the University of Ghana. I would also like to thank an anonymous referee for detailed suggestions and helpful comments. I am grateful to Occy Banful and William Baah Boateng for invaluable research assistance.

\section{REFERENCES}

Alesina, A., Baqir, R. and Easterly, W., 1999. Public Goods and Ethnic Divisions. Quarterly Journal of Economics 114 (4), 1243-1284.

Alesina, A., Baqir, R. and Hoxby, C., 2004. Political Jurisdictions in Heterogeneous

Communities. Journal of Political Economy 112 (2), 348-396.

Anderson, G. and Tollison, R., 1991. Congressional Influence and Patterns of New Deal Spending. 1933-1939. Journal of Law and Economics 34, 161-175. 
Arulampalam,W., Dasgupta, S., Dhillon, A. and Dutta, B., 2009. Electoral goals and center-state transfers: A theoretical model and empirical evidence from India. Journal of Development Economics 88 (1), 103-119.

Ayee, Joseph. 1994. Anatomy of Public Policy Implementation: The Case of Decentralization Policies in Ghana. United Kingdom: Ashgate Publishing Limited. . 2003. Towards Effective and Accountable Local Government in Ghana. Ghana Center for Democratic Development, Critical Perspectives 13.

Bardhan, P. and Mookherjee, D., 2005. Decentralization, Corruption and Government Accountability: An Overview. In International Handbook on the Economics of Corruption, Susan Rose-Ackerman ed. Williston, VT: Edward Elgar. . 2002. Relative Capture of Local and Central Governments: An Essay in the Political Economy of Decentralization. CIDER Working Paper C99-109. . 2000. Capture and Governance at Local and National Levels. American Economic

Review, 90 (2), 135-139.

Barkan, J. and Chege, M., 1989. Decentralising the State: District Focus and the Politics of Reallocation in Kenya. Journal of Modern African Studies 27 (3), 431-453.

Buchanan, J. 1950. Federalism and fiscal equity. American Economic Review 40 (4), 583-599. , and Charles J. Goetz. 1972. Efficiency limits of fiscal mobility; An assessment of the

Tiebout Model. Journal of Public Economics, 1 (1), 25-43.

Case, A., 2001. Election goals and income redistribution; recent evidence from Albania. European Economic Review 45, 405-423.

Cole, S., 2009. Fixing Market Failures or Fixing Elections? Agricultural Credit in India. American Economic Journal: Applied Economics, 1(1), 219-250. 
Khemani, S., 2003. Partisan politics and intergovernmental transfers in India. Policy Research Working Paper

Cox, G., and McCubbins, M., 1986. Electoral Politics as a Redistributive Game. Journal of Politics 48 (2), 370-389.

Dahlberg, M. and Johansson, E., 2002. On the Vote-Purchasing Behavior of Incumbent Governments. The American Political Science Review, 96 (1), 27-40.

Dixit, A. and Londregan, J., 1996. The Determinants of Success of Special Interests in Redistributive Politics. Journal of Politics 58 (4), 1132-1155.

Dixit, A. and Londregan, J., 1998. Ideology, Tactics, and Efficiency in Redistributive Politics. Quarterly Journal of Economics 113 (1), 497-529.

Easterly, W. and Levine, R., 1997. Africa's Growth Tragedy: Policies and Ethnic Divisions. Quarterly Journal of Economics 112, (4), 1203-1250.

Epple, D. and Zelnitz, A., 1981. The Implications of Competition Among Jurisdictions: Does Tiebout Need Politics? Journal of Political Economy, 89 (6), 1197-1217.

Epple, D., Filimon, R. and Romer, T., 1984. Equilibrium Among Local Jurisdictions: Toward an Integrated Treatment of Voting and Residential Choice. Journal of Public Economics, 24 (3), 281-308.

Eriksen, S., Naustdalslid, J. and Schou, A., 1999. Decentralization from Above. A Study of Local Government in Botswana, Ghana, Tanzania and Zimbabwe. NIBR Series 4-99.

Grossman, P. 1994. A political theory of intergovernmental grants. Public Choice 78, 295-303.

Johansson, E., 2003. Intergovernmental Grants as a Tactical Instrument: Empirical Evidence from Swedish Municipalities. Journal of Public Economics 87 (5), 883-915. 
Kasara, K., 2007. Tax Me If You Can: Ethnic Geography, Democracy, and the Taxation of Agriculture in Africa. American Political Science Review 101 (1), 159-172.

Khemani, S., 2003. Partisan Politics and Intergovernmental Transfers in India. World Bank Policy Research Working Paper 3016.

Khemani, S., 2007. Does delegation of fiscal policy to an independent agency make a difference? Evidence from intergovernmental transfers in India. Journal of Development Economics 82, $464-484$.

Levitt, S. and Snyder, J., 1997. The Impact of Federal Spending on House Election Outcomes. Journal of Political Economy 105, 30-53.

Lindbeck, A. and Weibull, J., 1993. A Model of Political Equilibrium in a Representative Democracy. Journal of Public Economics 51 (2), 195-209.

Massing, A., 1994. Local Government Reform in Ghana; Democratic Renewal or Autocratic Revival? Germany: Verlag für Entwicklungspolitik Breitenbach.

Miguel, E., 2004. Tribe or Nation? Nation-Building and Public Goods in Kenya versus Tanzania. World Politics, 56 (3), 327-362. and Zaidi, F., 2003. Do Politicians Reward their Supporters? Regression Discontinuity

Evidence from Ghana. Mimeo, University of California, Berkeley.

Miguel, E. and Gugerty, M., 2005. Ethnic Divisions, Social Sanctions, and Public Goods in Kenya. Journal of Public Economics, 89 (11), 2325-2368.

Musgrave, R., 1959. The theory of public finance; A study in public economy. New York. Oates W., 1972. Fiscal Federalism. New York; Harcourt Brace Janovich. , 1991. Studies in Fiscal Federalism. Great Britain; Edward Elgar. 
_ 1997. On the Welfare Gains from Fiscal Decentralization. Journal of Public Finance and Public Choice 2 (3), 83-92. , 1999. An Essay on Fiscal Federalism. Journal of Economic Literature, 37 (3), 1120-1149

Pereyra, P., 1996. A politico-economic approach to intergovernmental lump-sum grants. Public Choice 88, 185-201.

Persson, T., Gerard Roland, G. and Tabellini, G., 1997. Separation of Powers and Political Accountability. Quarterly Journal of Economics, 112, (4), 1163-1202.

Porto, A., Sanguinetti, P., 2001. Political determinants of intergovernmental grants: evidence from Argentina. Economics and Politics 13, 237-256.

Samuelson, P., 1954. The Pure Theory of Public Expenditures. Review of Economics and Statistics, XXXVI, No. 4.

Veiga, L. and Pinho, M., 2007. The political economy of intergovernmental grants: Evidence from a maturing democracy. Public Choice 133, 457-477.

Wallis, J., 1997. What Determines the Allocation of National Government Grants to the States?

NBER Working Paper on Historical Factors in Long Run Growth 90.

Wallis, J., 1998. The Political Economy of New Deal Spending, Revisited, With and Without Nevada. Explorations in Economic History 35, 140-170.

Worthington, A. and Dollery, B., 1998. The Political Determination of Intergovernmental Grants in Austria. Public Choice 94, 299-315.

Wright, G., 1974. The Political Economy of New Deal Spending: An Econometric Analysis. Review of Economics and Statistics 56, 30-38. 

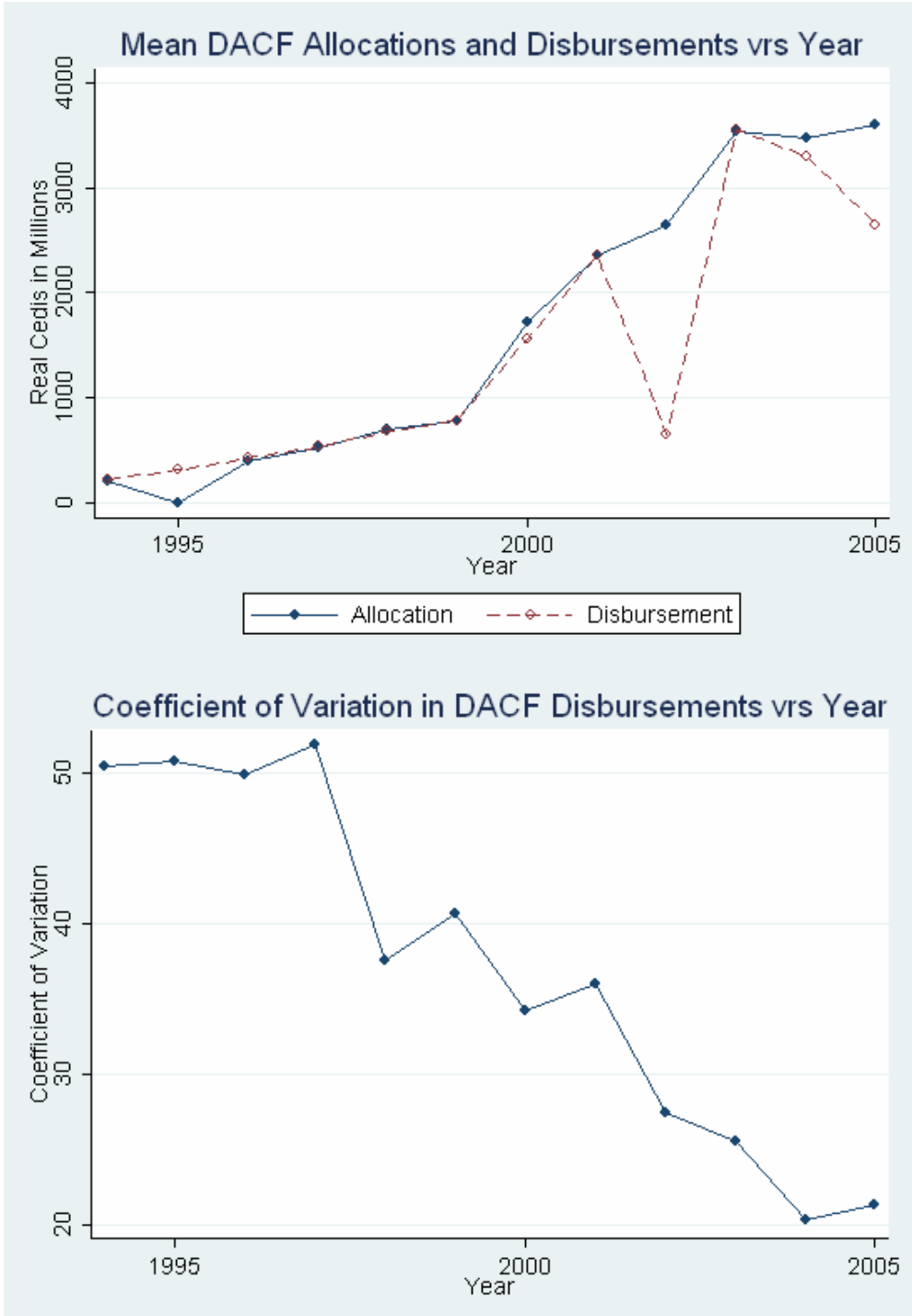

Figure 1: Graphical Presentation Of Statistics Of Real DACF Allocations And Disbursements 
Table 1 - Variables And Weights Used In Calculating DACF Allocations

\begin{tabular}{|c|c|c|c|c|c|c|c|c|c|c|c|c|}
\hline \multirow[b]{2}{*}{ Factor } & \multicolumn{12}{|c|}{ Percentage Weight in District Assembly Common Fund Formula in Year: } \\
\hline & 1994 & 1995 & 1996 & 1997 & 1998 & 1999 & 2000 & 2001 & 2002 & 2003 & 2004 & 2005 \\
\hline 'Need' & 35 & 35 & 35 & 35 & 35 & 35 & 40 & 40 & 50 & 55 & 35 & 35 \\
\hline GDP per capita(1992) & 30 & 30 & 15 & 10 & 10 & 5 & & & & & & \\
\hline Population & 5 & 5 & & & & & & & & & & \\
\hline Health facilities & & & 10 & 12.5 & 12.5 & 15 & 12.5 & 12.5 & 12.5 & 12.5 & 5 & 5 \\
\hline Population/Doctor & & & & & & & 7.5 & 7.5 & 7.5 & 7.5 & 5 & 5 \\
\hline Population/Nurse & & & & & & & & & & & 5 & 5 \\
\hline Education facilities & & & 10 & 12.5 & 12.5 & 15 & 12.5 & 12.5 & 12.5 & 12.5 & 5 & 5 \\
\hline Pupils/Teacher & & & & & & & 7.5 & 7.5 & 7.5 & 7.5 & 5 & 5 \\
\hline Water coverage & & & & & & & & & 10 & 10 & 5 & 4 \\
\hline Tarred Roads mileage & & & & & & & & & & & 5 & 6 \\
\hline Dilapidated Schools & & & & & & & & & & 5 & & \\
\hline 'Responsiveness' & 20 & 20 & 20 & 20 & 20 & 20 & 15 & 15 & 5 & 5 & 2 & 3 \\
\hline Revenue per capita & 20 & 20 & 15 & 15 & 15 & 15 & 10 & 10 & & & & \\
\hline $\begin{array}{l}\text { Increase in revenue } \\
\text { per capita }\end{array}$ & & & 5 & 5 & 5 & 5 & 5 & 5 & 5 & & & \\
\hline Increase in Revenue & & & & & & & & & & 5 & 2 & 3 \\
\hline 'Service Pressure' & 15 & 15 & 15 & 15 & 10 & 10 & 10 & 10 & 10 & 5 & 3 & 2 \\
\hline Population Density & 15 & 15 & 15 & 15 & 10 & 10 & 10 & 10 & 10 & 5 & 3 & 2 \\
\hline 'Equality' & 30 & 30 & 30 & 30 & 35 & 35 & 35 & 35 & 35 & 35 & 60 & 60 \\
\hline
\end{tabular}

Note: Due to transformation of variables before weighted linear combination, district DACF share is decreasing in GDP per capita (1992), health facilities,

education facilities, water coverage, and mileage of tarred roads. District DACF share is increasing in population, population per doctor, population per nurse, pupils/teacher, dilapidated schools, revenue per capita, increase in revenue per capita, increase in revenue, and population density. 
Table 2 - Summary Statistics Of DACF Data

\begin{tabular}{|c|c|c|c|c|c|}
\hline Variable & Observations & Mean & Std. Dev. & Min & Max \\
\hline $\begin{array}{l}\text { Real Allocation in Millions } \\
\text { (2000 Cedis) }\end{array}$ & 1266 & 1890 & 1440 & 138 & 8590 \\
\hline $\begin{array}{l}\text { Real Disbursements in } \\
\text { Millions (2000 Cedis) }\end{array}$ & 1376 & 1490 & 1290 & 156 & 8650 \\
\hline Disbursement/Allocation & 1266 & 0.91 & 0.23 & 0.25 & 1.53 \\
\hline Share of DACF fund & 1018 & 0.0088 & 0.0034 & 0.0056 & 0.0451 \\
\hline Population & 1376 & 155581 & 162946 & 42721 & 1658937 \\
\hline $\begin{array}{l}\text { Population Density (persons } \\
\text { per } \mathrm{m}^{2} \text { ) }\end{array}$ & 1376 & 0.0172 & 0.0212 & 0.0002 & 0.1904 \\
\hline Hospitals & 1018 & 12.53 & 17.01 & 1.00 & 198.00 \\
\hline Doctors & 578 & 5.49 & 12.66 & 1.00 & 161.00 \\
\hline $\begin{array}{l}\text { Nurses } \\
\text { Enrolment in Elementary }\end{array}$ & 138 & 41.83 & 91.84 & 2.00 & 959.00 \\
\hline School & 578 & 25975 & 21585 & 5620 & 261658 \\
\hline $\begin{array}{l}\text { Elementary School Teachers } \\
\text { Length of Tarred Roads }\end{array}$ & 578 & 893 & 746 & 54 & 7307 \\
\hline $\begin{array}{l}\text { (Km) } \\
\text { Percentage District with }\end{array}$ & 138 & 64.11 & 87.35 & 0.05 & 791.75 \\
\hline pipe-borne water & 358 & 41.44 & 20.90 & 3.97 & 100.00 \\
\hline Schools & 1018 & 161 & 83 & 39 & 740 \\
\hline $\begin{array}{l}\text { Proportion of Schools that } \\
\text { are Dilapidated } \\
\text { Locally raised revenue in }\end{array}$ & 166 & 0.34 & 0.08 & 0.15 & 0.58 \\
\hline Millions (Nominal Cedis) & 660 & 464 & 1810 & 16.3 & 29900 \\
\hline $\begin{array}{l}\text { Locally raised revenue per } \\
\text { capita (Nominal Cedis) } \\
\text { Annual Percentage change in }\end{array}$ & 880 & 1563 & 1852 & 60 & 18022 \\
\hline $\begin{array}{l}\text { Annual Percentage change in } \\
\text { Locally raised revenue } \\
\text { (Nominal Cedis) } \\
\text { Annual Percentage change in }\end{array}$ & 798 & 46.92 & 111.60 & -88.73 & 1619.28 \\
\hline $\begin{array}{l}\text { Locally raised revenue per } \\
\text { capita } \\
\text { Gross Domestic Product in }\end{array}$ & 770 & 61.87 & 146.08 & -87.56 & 1939.74 \\
\hline 1992 (Nominal Cedis) & 110 & 374 & 128 & 133 & 846 \\
\hline
\end{tabular}

Unless otherwise stated, statistics calculated based on values from 1994 to 2005 
Table 3- Summary Statistics Of Election Data

\begin{tabular}{|c|c|c|c|c|c|}
\hline Variable Description & Observations & Mean & Std. Dev. & Min & Max \\
\hline $\begin{array}{l}\text { Ruling party won district in presidential election } \\
1992\end{array}$ & 110 & 0.79 & 0.41 & 0 & 1 \\
\hline $\begin{array}{l}\text { Margin of Victory in presidential election } 1992 \\
\text { Ruling party vote percentage in presidential election } \\
\text { in } 1992\end{array}$ & 110 & 38.93 & 18.50 & 13.56 & 94.79 \\
\hline $\begin{array}{l}\text { Ruling party won district in presidential election } \\
1996\end{array}$ & 110 & 0.73 & 0.45 & 0 & 1 \\
\hline Ruling Party won parliamentary elections 1996 & 110 & 0.74 & 0.44 & 0 & 1 \\
\hline Margin of Victory in presidential elections 1996 & 110 & 37.14 & 27.38 & 0.46 & 96.85 \\
\hline $\begin{array}{l}\text { Margin of Victory in parliamentary elections in } 1996 \\
\text { Ruling party vote percentage in presidential election } \\
1996 \\
\text { Ruling party vote percentage in parliamentary } \\
\text { election } 1996\end{array}$ & 110 & 32.90 & 19.57 & 23.34 & 99.00 \\
\hline $\begin{array}{l}\text { Ruling party won district in } 2000 \text { run-off presidential } \\
\text { election }\end{array}$ & 110 & 0.62 & 0.49 & 0 & 1 \\
\hline $\begin{array}{l}\text { Ruling Party won parliamentary elections } 2000 \\
\text { Margin of Victory in } 2000 \text { run-off presidential } \\
\text { election }\end{array}$ & 110 & 33.86 & 23.59 & 0.07 & 91.48 \\
\hline $\begin{array}{l}\text { Margin of Victory in parliamentary elections in } 2000 \\
\text { Ruling party vote percentage } 2000 \text { run-off } \\
\text { presidential election } \\
\text { Ruling party vote percentage in parliamentary } \\
\text { election } 2000\end{array}$ & 110 & 41.97 & $\begin{array}{l}22.88 \\
22.64\end{array}$ & 0.99 & $\begin{array}{l}85.18 \\
80.91\end{array}$ \\
\hline $\begin{array}{l}\text { Ruling party won district in presidential election } \\
2004\end{array}$ & 138 & 0.55 & 0.50 & 0 & 1 \\
\hline Ruling Party won parliamentary elections 2004 & 138 & 0.55 & 0.50 & 0 & 1 \\
\hline Margin of Victory in presidential elections in 2004 & 138 & 30.82 & 22.21 & 0.41 & 89.25 \\
\hline $\begin{array}{l}\text { Margin of Victory in parliamentary elections in } 2004 \\
\text { Ruling party vote percentage in presidential election } \\
2004 \\
\text { Ruling party vote percentage in parliamentary } \\
\text { election } 2004\end{array}$ & 138 & $\begin{array}{l}48.30 \\
45.05 \\
\end{array}$ & $\begin{array}{l}20.18 \\
19.18 \\
\end{array}$ & $\begin{array}{l}4.25 \\
0.00 \\
\end{array}$ & $\begin{array}{l}88.20 \\
84.20 \\
\end{array}$ \\
\hline $\begin{array}{l}\text { Either NDC or NPP won district in presidential } \\
\text { election } 1992 \\
\text { Either NDC or NPP won district in presidential } \\
\text { election } 1996 \\
\text { Either NDC or NPP won district in presidential } \\
\text { election } 2000 \\
\text { Either NDC or NPP won district in presidential } \\
\text { election } 2004\end{array}$ & 110 & 0.96 & 0.18 & 1 & 1 \\
\hline Split in 2004 redistricting & 110 & 0.25 & 0.44 & 0 & 1 \\
\hline Area $\left(\mathrm{Km}^{2}\right)$ before 2004 redistricting & 110 & 2172 & 2561 & 122 & 17440 \\
\hline $\operatorname{Area}\left(\mathrm{Km}^{2}\right)$ after 2004 redistricting & 138 & 1720 & 1793 & 150 & 12955 \\
\hline
\end{tabular}


Table 4: FE estimation results providing evidence of tactical distribution of DACF endowment

\begin{tabular}{|c|c|c|c|c|c|c|}
\hline & \multicolumn{6}{|c|}{ Dependent Variable: Ln Per capita real DACF disbursement } \\
\hline & \multicolumn{2}{|c|}{$\begin{array}{c}\text { POLTCS }=\text { Vote margin } \\
\text { between parties }\end{array}$} & \multicolumn{2}{|c|}{$\begin{array}{c}\text { POLTCS }=\text { Vote share of } \\
\text { ruling party }\end{array}$} & \multicolumn{2}{|c|}{$\begin{array}{c}\text { POLTCS = Ruling party won } \\
\text { dummy }\end{array}$} \\
\hline & (1a) & (1b) & (2a) & (2b) & (3a) & $(3 b)$ \\
\hline \multirow[t]{2}{*}{ POLTCS } & $-0.0012 * * *$ & -0.0011 & $-0.0008 * * *$ & $-0.0021 *$ & $-0.0546 * * *$ & $-0.1890 * * *$ \\
\hline & $(0.0004)$ & $(0.0010)$ & $(0.0003)$ & $(0.0012)$ & $(0.0137)$ & $(0.0482)$ \\
\hline \multirow[t]{2}{*}{ POLTCS $\times 1994$} & & 0.0010 & & 0.0015 & & $0.188 * *$ \\
\hline & & $(0.0012)$ & & $(0.0020)$ & & $(0.0737)$ \\
\hline \multirow[t]{2}{*}{ POLTCS $\times 1995$} & & 0.0008 & & 0.0017 & & $0.2000 * * *$ \\
\hline & & $(0.0012)$ & & $(0.0020)$ & & $(0.0737)$ \\
\hline \multirow[t]{2}{*}{ POLTCS × 1996} & & 0.0001 & & 0.0006 & & $0.1520 * *$ \\
\hline & & $(0.0012)$ & & $(0.0020)$ & & $(0.0737)$ \\
\hline \multirow[t]{2}{*}{ POLTCS $\times 1997$} & & $-0.0019 *$ & & -0.0012 & & $0.1230 *$ \\
\hline & & $(0.0011)$ & & $(0.0021)$ & & $(0.0717)$ \\
\hline \multirow[t]{2}{*}{ POLTCS $\times 1998$} & & -0.0008 & & 0.0005 & & $0.1710 * *$ \\
\hline & & $(0.0011)$ & & $(0.0021)$ & & $(0.0717)$ \\
\hline \multirow[t]{2}{*}{ POLTCS $\times 1999$} & & -0.0002 & & 0.0019 & & $0.1880 * * *$ \\
\hline & & $(0.0011)$ & & $(0.0021)$ & & $(0.0717)$ \\
\hline \multirow[t]{2}{*}{ POLTCS $\times 2000$} & & 0.0000 & & 0.0014 & & $0.1810 * *$ \\
\hline & & $(0.0011)$ & & $(0.0021)$ & & $(0.0717)$ \\
\hline \multirow[t]{2}{*}{ POLTCS $\times 2001$} & & 0.0010 & & $0.0021 *$ & & $0.1160 *$ \\
\hline & & $(0.0012)$ & & $(0.0013)$ & & $(0.0595)$ \\
\hline \multirow[t]{2}{*}{ POLTCS $\times 2002$} & & -0.0004 & & 0.0018 & & $0.1300^{* *}$ \\
\hline & & $(0.0012)$ & & $(0.0013)$ & & $(0.0595)$ \\
\hline \multirow[t]{2}{*}{ POLTCS $\times 2003$} & & -0.0003 & & $0.0038 * * *$ & & $0.1960 * * *$ \\
\hline & & $(0.0012)$ & & $(0.0013)$ & & $(0.0604)$ \\
\hline \multirow[t]{2}{*}{ POLTCS $\times 2004$} & & $9.38 \mathrm{E}-05$ & & -0.0007 & & 0.0088 \\
\hline & & $(0.0011)$ & & $(0.0011)$ & & $(0.0633)$ \\
\hline \multirow[t]{2}{*}{ Wealth proxy } & $-0.0027 * * *$ & $-0.0027 * * *$ & $-0.0025 * * *$ & $-0.0028 * * *$ & $-0.0024 * * *$ & $-0.0026 * * *$ \\
\hline & $(0.0004)$ & $(0.0004)$ & $(0.0004)$ & $(0.0004)$ & $(0.0004)$ & $(0.0004)$ \\
\hline Year Dummies & YES & YES & YES & YES & YES & YES \\
\hline \multirow[t]{2}{*}{ Constant } & $10.32 * * *$ & $10.32 * * *$ & $10.30 * * *$ & $10.40 * * *$ & $10.28 * * *$ & $10.38 * * *$ \\
\hline & $(0.07)$ & $(0.07)$ & -0.0677 & $(0.09)$ & -0.0678 & $(0.08)$ \\
\hline Observations & 1376 & 1376 & 1376 & 1376 & 1376 & 1320 \\
\hline R-squared & 0.955 & 0.955 & 0.955 & 0.956 & 0.955 & 0.956 \\
\hline
\end{tabular}

$* * * \mathrm{p}<0.01, * * \mathrm{p}<0.05, * \mathrm{p}<0.1$ Standard errors in parentheses. Omitted year in year and year interaction dummies is 2005 . The district wealth is proxied by the number of schools in the district. 
Table 5: FE estimation results providing evidence of tactical sharing of DACF endowment

Dependent Variable: Ln Real Per Capita DACF Allocation

\begin{tabular}{|c|c|c|c|c|c|c|}
\hline & \multicolumn{2}{|c|}{$\begin{array}{c}\text { POLTCS }=\text { Vote margin } \\
\text { between parties }\end{array}$} & \multicolumn{2}{|c|}{$\begin{array}{c}\text { POLTCS }=\text { Vote share of } \\
\text { ruling party }\end{array}$} & \multicolumn{2}{|c|}{$\begin{array}{l}\text { POLTCS = Ruling party } \\
\text { won dummy }\end{array}$} \\
\hline & (1a) & $(1 b)$ & (2a) & (2b) & (3a) & (3b) \\
\hline \multirow[t]{2}{*}{ POLTCS } & $-0.0012 * * *$ & -0.0013 & $-0.0008 * *$ & $-0.0027 * *$ & $-0.0520 * * *$ & $-0.1920 * * *$ \\
\hline & $(0.0005)$ & $(0.0010)$ & $(0.0003)$ & $(0.0013)$ & $(0.0140)$ & $(0.0488)$ \\
\hline \multirow[t]{2}{*}{ POLTCS $\times 1994$} & & 0.0012 & & 0.0029 & & $0.212 * * *$ \\
\hline & & $(0.0012)$ & & $(0.0022)$ & & $(0.0746)$ \\
\hline \multirow[t]{2}{*}{ POLTCS × 1996} & & 0.0004 & & 0.0018 & & $0.1640 * *$ \\
\hline & & $(0.0012)$ & & $(0.0022)$ & & $(0.0746)$ \\
\hline \multirow[t]{2}{*}{ POLTCS $\times 1997$} & & -0.0010 & & 0.0007 & & $0.1610 * *$ \\
\hline & & $(0.0011)$ & & $(0.0022)$ & & $(0.07310)$ \\
\hline \multirow[t]{2}{*}{ POLTCS × 1998} & & -0.0011 & & 0.0020 & & $0.2050 * * *$ \\
\hline & & $(0.0011)$ & & $(0.0022)$ & & $(0.0732)$ \\
\hline \multirow[t]{2}{*}{ POLTCS $\times 1999$} & & -0.0001 & & 0.0029 & & $0.2000 * * *$ \\
\hline & & $(0.0011)$ & & $(0.0022)$ & & $(0.0732)$ \\
\hline \multirow[t]{2}{*}{ POLTCS $\times 2000$} & & 0.0004 & & 0.0027 & & $0.2060 * * *$ \\
\hline & & $(0.0011)$ & & $(0.0022)$ & & $(0.0732)$ \\
\hline \multirow[t]{2}{*}{ POLTCS $\times 2001$} & & 0.0012 & & $0.0023^{*}$ & & $0.1090^{*}$ \\
\hline & & $(0.0013)$ & & $(0.0013)$ & & $(0.0597)$ \\
\hline \multirow[t]{2}{*}{ POLTCS $\times 2002$} & & -0.00021 & & 0.0021 & & $0.1230 * *$ \\
\hline & & $(0.0012)$ & & $(0.0013)$ & & $(0.0597)$ \\
\hline \multirow[t]{2}{*}{ POLTCS $\times 2003$} & & $-5.74 \mathrm{E}-05$ & & $0.0037 * * *$ & & $0.1770 * * *$ \\
\hline & & $(0.0012)$ & & $(0.0013)$ & & $(0.0606)$ \\
\hline \multirow[t]{2}{*}{ POLTCS $\times 2004$} & & 0.0004 & & -0.0005 & & -0.0006 \\
\hline & & $(0.0011)$ & & $(0.0011)$ & & $(0.0634)$ \\
\hline \multirow[t]{2}{*}{ Wealth proxy } & $-0.0022 * * *$ & $-0.0022 * * *$ & $-0.0021 * * *$ & $-0.0023 * * *$ & $-0.0020 * * *$ & $-0.0021 * * *$ \\
\hline & $(0.0004)$ & $(0.0004)$ & $(0.0004)$ & $(0.0004)$ & $(0.0004)$ & $(0.0004)$ \\
\hline Year Dummies & YES & YES & YES & YES & YES & YES \\
\hline \multirow[t]{2}{*}{ Constant } & $10.55 * * *$ & $10.55 * * *$ & $10.52 * * *$ & $10.66 * * *$ & $10.50 * * *$ & $10.60 * * *$ \\
\hline & $(0.07)$ & $(0.08)$ & $(0.07)$ & $(0.09)$ & $(0.07)$ & $(0.08)$ \\
\hline Observations & 1266 & 1266 & 1266 & 1266 & 1266 & 1210 \\
\hline R-squared & 0.96 & 0.96 & 0.96 & 0.96 & 0.96 & 0.96 \\
\hline
\end{tabular}

*** $\mathrm{p}<0.01, * * \mathrm{p}<0.05, * \mathrm{p}<0.1$ Standard errors in parentheses. No observation from 1995 available. Omitted year in year and year interaction dummies is 2005 . The district wealth is proxied by the number of schools in the district. 
Table 6 - FE estimation results providing evidence of political motivation in DACF formula changes

\begin{tabular}{|c|c|c|c|c|c|c|}
\hline & \multicolumn{6}{|c|}{ Dependent variable: $\ln$ (Actual allocation/Counter factual allocation) } \\
\hline & \multicolumn{2}{|c|}{$\begin{array}{c}\text { POLTCS }=\text { Vote margin } \\
\text { between parties }\end{array}$} & \multicolumn{2}{|c|}{$\begin{array}{c}\text { POLTCS }=\text { Vote share of } \\
\text { ruling party }\end{array}$} & \multicolumn{2}{|c|}{$\begin{array}{c}\text { POLTCS = Ruling party won } \\
\text { district }\end{array}$} \\
\hline & (1a) & (1b) & (2a) & $(2 b)$ & (3a) & $(3 b)$ \\
\hline \multirow[t]{2}{*}{ POLTCS } & -0.0009 & -0.0009 & -0.0019 & -0.0019 & $-0.1230 * * *$ & $-0.1210 * * *$ \\
\hline & $(0.0009)$ & $(0.0009)$ & $(0.0012)$ & $(0.0012)$ & $(0.0435)$ & $(0.0435)$ \\
\hline \multirow[t]{2}{*}{ POLTCS $\times 1996$} & -0.0009 & -0.0008 & 0.0005 & 0.0006 & 0.0197 & 0.0200 \\
\hline & $(0.0011)$ & $(0.0011)$ & $(0.0021)$ & $(0.0021)$ & $(0.0667)$ & $(0.0667)$ \\
\hline \multirow[t]{2}{*}{ POLTCS × 1997} & $-0.0017 *$ & -0.0017 & -0.0001 & 0.0000 & 0.0550 & 0.0563 \\
\hline & $(0.0010)$ & $(0.0010)$ & $(0.0021)$ & $(0.0021)$ & $(0.0661)$ & $(0.0661)$ \\
\hline \multirow[t]{2}{*}{ POLTCS × 1998} & 0.0003 & 0.0004 & 0.0027 & 0.0028 & 0.1070 & 0.1090 \\
\hline & $(0.0010)$ & $(0.0010)$ & $(0.0021)$ & $(0.0021)$ & $(0.0661)$ & $(0.0661)$ \\
\hline \multirow[t]{2}{*}{ POLTCS × 1999} & -0.0002 & -0.0002 & 0.0032 & 0.0033 & $0.1530 * *$ & $0.1540 * *$ \\
\hline & $(0.0010)$ & $(0.0010)$ & $(0.0021)$ & $(0.0021)$ & $(0.0661)$ & $(0.0661)$ \\
\hline \multirow[t]{2}{*}{ POLTCS $\times 2000$} & -0.0015 & -0.0014 & 0.0011 & 0.0012 & $0.1360 * *$ & $0.1370 * *$ \\
\hline & $(0.0010)$ & $(0.0010)$ & $(0.0021)$ & $(0.0021)$ & $(0.0661)$ & $(0.0661)$ \\
\hline \multirow[t]{2}{*}{ POLTCS × 2001} & 0.0014 & 0.0014 & 0.0002 & 0.0002 & 0.0191 & 0.0191 \\
\hline & $(0.0010)$ & $(0.0010)$ & $(0.0011)$ & $(0.0011)$ & $(0.0525)$ & $(0.0525)$ \\
\hline \multirow[t]{2}{*}{ POLTCS × 2002} & -0.0003 & -0.0003 & $0.0024 * *$ & $0.0024 * *$ & $0.1280 * *$ & $0.1270 * *$ \\
\hline & $(0.0010)$ & $(0.0010)$ & $(0.0011)$ & $(0.0011)$ & $(0.0525)$ & $(0.0525)$ \\
\hline \multirow[t]{2}{*}{ POLTCS $\times 2003$} & 0.0007 & 0.0007 & 0.0016 & $0.0020 *$ & 0.0849 & $0.0982 *$ \\
\hline & $(0.0010)$ & $(0.0010)$ & $(0.0011)$ & $(0.0011)$ & $(0.0525)$ & $(0.0533)$ \\
\hline \multirow[t]{2}{*}{ POLTCS × 2004} & 0.0014 & 0.0014 & $-0.0020 * *$ & $-0.0020 * *$ & -0.0774 & -0.0762 \\
\hline & $(0.0009)$ & $(0.0009)$ & $(0.0010)$ & $(0.0010)$ & $(0.0557)$ & $(0.0557)$ \\
\hline \multirow[t]{2}{*}{ Schools } & & -0.0006 & & $-0.0007 *$ & & -0.0006 \\
\hline & & $(0.0004)$ & & $(0.0004)$ & & $(0.0004)$ \\
\hline \multirow[t]{2}{*}{ Constant } & 0.010 & 0.100 & 0.078 & $0.184 * *$ & $0.059 *$ & $0.150 * *$ \\
\hline & $(0.032)$ & $(0.069)$ & $(0.061)$ & $(0.088)$ & $(0.032)$ & $(0.072)$ \\
\hline Observations & 1156 & 1156 & 1156 & 1156 & 1100 & 1100 \\
\hline R-squared & 0.03 & 0.04 & 0.05 & 0.05 & 0.05 & 0.06 \\
\hline
\end{tabular}




\section{APPENDIX: SUPPLEMENTARY MATERIALS}

Table 7 - Functions of Variables As Used In DACF Formula

\begin{tabular}{|c|c|}
\hline Variable & Function to which weight in formula is applied \\
\hline \multirow[t]{2}{*}{ GDP(1992) } & $\mathrm{Y}_{\mathrm{i}}=$ GDP per capita of District i \\
\hline & $1 /\left(\mathrm{Y}_{\mathrm{i}}\right) / \sum\left(1 / \mathrm{Y}_{\mathrm{i}}\right)$ \\
\hline Population & $\begin{array}{l}\mathrm{P}_{\mathrm{i}}=\text { Population of District } \mathrm{i} \\
\left(\mathrm{P}_{\mathrm{i}} / \sum \mathrm{P}_{\mathrm{i}}\right)\end{array}$ \\
\hline \multirow[t]{2}{*}{ Health facilities } & $\mathrm{H}_{\mathrm{i}}=$ Health Facilities in District $\mathrm{i}$ \\
\hline & $1 /\left\{\left(\mathrm{H}_{\mathrm{i}} / \sum \mathrm{H}_{\mathrm{i}}\right) /\left(\mathrm{P}_{\mathrm{i}} / \sum \mathrm{P}_{\mathrm{i}}\right)\right\} / \sum\left\{\left(1 /\left(\mathrm{H}_{\mathrm{i}} / \sum \mathrm{H}_{\mathrm{i}}\right) /\left(\mathrm{P}_{\mathrm{i}} / \sum \mathrm{P}_{\mathrm{i}}\right)\right\}\right.$ \\
\hline \multirow[t]{2}{*}{ Population/Doctor } & $\begin{array}{l}\mathrm{D}_{\mathrm{i}}=\text { Doctors in District } \mathrm{i} \\
\mathrm{P}_{\mathrm{i}}=\text { Population of District } \mathrm{i}\end{array}$ \\
\hline & $1 /\left\{\left(\mathrm{D}_{\mathrm{i}} / \sum \mathrm{Di}\right) /\left(\mathrm{P}_{\mathrm{i}} / \sum \mathrm{P}_{\mathrm{i}}\right)\right\} / \sum\left\{\left(1 /\left(\mathrm{D}_{\mathrm{i}} / \sum \mathrm{D}_{\mathrm{i}}\right) /\left(\mathrm{P}_{\mathrm{i}} / \sum \mathrm{P}_{\mathrm{i}}\right)\right\}\right.$ \\
\hline \multirow[t]{2}{*}{ Population/Nurse } & $\begin{array}{l}\mathrm{N}_{\mathrm{i}}=\text { Nurses in District } \mathrm{i} \\
\mathrm{P}_{\mathrm{i}}=\text { Population of District } \mathrm{i}\end{array}$ \\
\hline & $1 /\left\{\left(\mathrm{N}_{\mathrm{i}} / \sum \mathrm{N}_{\mathrm{i}}\right) /\left(\mathrm{P}_{\mathrm{i}} / \sum \mathrm{P}_{\mathrm{i}}\right)\right\} / \sum\left\{\left(1 /\left(\mathrm{N}_{\mathrm{i}} / \sum \mathrm{N}_{\mathrm{i}}\right) /\left(\mathrm{P}_{\mathrm{i}} / \sum \mathrm{P}_{\mathrm{i}}\right)\right\}\right.$ \\
\hline \multirow[t]{2}{*}{ Education facilities } & $\begin{array}{l}\mathrm{E}_{\mathrm{i}}=\text { Education Facilities in District } \mathrm{i} \\
\mathrm{P}_{\mathrm{i}}=\text { Population of District } \mathrm{i}\end{array}$ \\
\hline & $1 /\left\{\left(\mathrm{E}_{\mathrm{i}} / \sum \mathrm{E}_{\mathrm{i}}\right) /\left(\mathrm{P}_{\mathrm{i}} / \sum \mathrm{P}_{\mathrm{i}}\right)\right\} / \sum\left\{\left(1 /\left(\mathrm{E}_{\mathrm{i}} / \sum \mathrm{E}_{\mathrm{i}}\right) /\left(\mathrm{P}_{\mathrm{i}} / \sum \mathrm{P}_{\mathrm{i}}\right)\right\}\right.$ \\
\hline \multirow[t]{2}{*}{$\begin{array}{l}\text { Education facilities In need of } \\
\text { major repair }\end{array}$} & $\begin{array}{l}E_{\mathrm{i}}=\text { Education Facilities in District } \mathrm{i} \\
\mathrm{DE}_{\mathrm{i}}=\text { Dilapidated Education Facilities in District } \mathrm{i}\end{array}$ \\
\hline & $\left\{\left(\mathrm{DE}_{\mathrm{i}} / \sum \mathrm{DE}_{\mathrm{i}}\right) /\left(\mathrm{E}_{\mathrm{i}} / \sum \mathrm{E}_{\mathrm{i}}\right)\right\} / \sum\left\{\left(\mathrm{DE}_{\mathrm{i}} / \sum \mathrm{DE}_{\mathrm{i}}\right) /\left(\mathrm{E}_{\mathrm{i}} / \sum \mathrm{E}_{\mathrm{i}}\right)\right\}$ \\
\hline \multirow[t]{2}{*}{ Pupil/Teacher } & $\begin{array}{l}\mathrm{T}_{\mathrm{i}}=\text { Teachers in District } \mathrm{i} \\
\mathrm{S}_{\mathrm{i}}=\text { Student enrolment of District } \mathrm{i}\end{array}$ \\
\hline & $1 /\left\{\left(\mathrm{T}_{\mathrm{i}} / \sum \mathrm{T}_{\mathrm{i}}\right) /\left(\mathrm{S}_{\mathrm{i}} / \sum \mathrm{S}_{\mathrm{i}}\right)\right\} / \sum\left\{\left(1 /\left(\mathrm{T}_{\mathrm{i}} / \sum \mathrm{T}_{\mathrm{i}}\right) /\left(\mathrm{S}_{\mathrm{i}} / \sum \mathrm{S}_{\mathrm{i}}\right)\right\}\right.$ \\
\hline \multirow[t]{2}{*}{ Water coverage } & $\begin{array}{l}W_{i}=\text { Percentage of District } i \text { with access to safe water source } \\
P_{i}=\text { Population of District } i\end{array}$ \\
\hline & $1 /\left\{\left(\mathrm{W}_{\mathrm{i}} / \sum \mathrm{W}_{\mathrm{i}}\right) /\left(\mathrm{P}_{\mathrm{i}} / \sum \mathrm{P}_{\mathrm{i}}\right)\right\} / \sum\left\{\left(1 /\left(\mathrm{W}_{\mathrm{i}} / \sum \mathrm{W}_{\mathrm{i}}\right) /\left(\mathrm{P}_{\mathrm{i}} / \sum \mathrm{P}_{\mathrm{i}}\right)\right\}\right.$ \\
\hline Revenue per capita & $\begin{array}{l}\mathrm{RP}_{\mathrm{i}}=\text { Revenue per Capita of District } \mathrm{i} \\
\left(\mathrm{RP}_{\mathrm{i}} / \sum \mathrm{RP}_{\mathrm{i}}\right)\end{array}$ \\
\hline Increase in revenue per capita* & $\begin{array}{l}\text { IncRP }_{i}=\text { Percentage increase in Revenue per Capita of District } i \\
\left(\operatorname{IncRP}_{i} / \sum \operatorname{IncRP} P_{i}\right)\end{array}$ \\
\hline Population Density & $\begin{array}{l}\mathrm{S}_{\mathrm{i}}=\text { Population Density of District } \mathrm{i} \\
\left(\mathrm{S}_{\mathrm{i}} / \sum \mathrm{S}_{\mathrm{i}}\right)\end{array}$ \\
\hline Increase in Revenue * & $\begin{array}{l}\text { IncR }_{i}=\text { Percentage increase in Revenue of District I } \\
\left(\operatorname{IncR}_{i} / \sum \mathrm{IncR}_{\mathrm{i}}\right)\end{array}$ \\
\hline
\end{tabular}


Table 8 - Dates Of Elections, Political Parties Contesting Presidential And Parliamentary

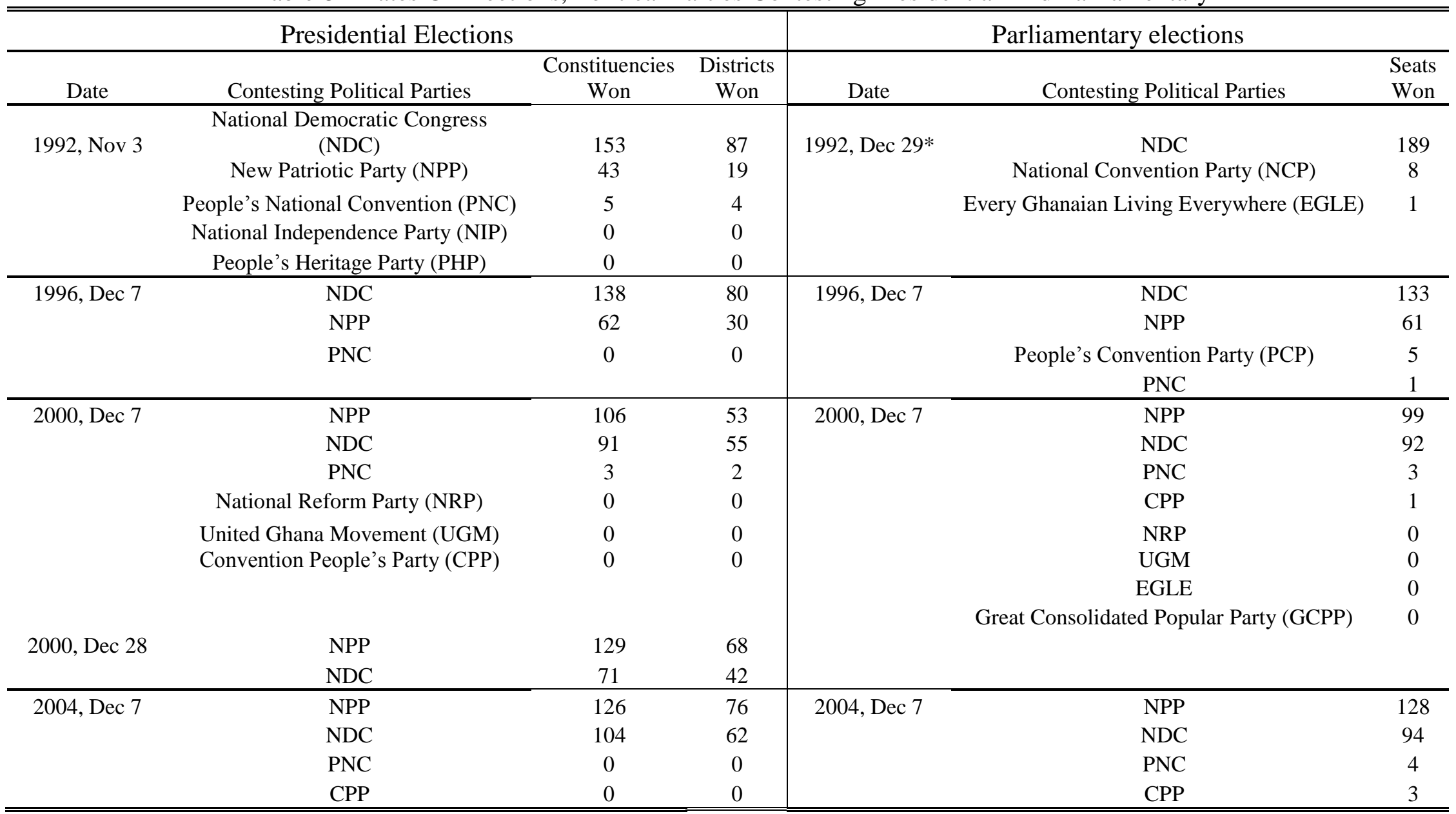

$\overline{\text { In 1992, } 1996 \text { and 2000, there were } 110 \text { districts and } 200 \text { constituencies in Ghana. In 2004, there were } 138 \text { districts and } 230 \text { constituencies. } * \text { Opposition parties }}$ boycotted 1992 Parliamentary Elections due to accusations of electoral fraud and malpractices and voter intimidation during the Presidential elections. 
Table 9- PROBIT regressions of the probability that a district was split in 2004 redistricting

\begin{tabular}{|c|c|c|c|}
\hline & \multicolumn{3}{|c|}{ Dependent Variable: Dummy for district split in 2004} \\
\hline & $\begin{array}{l}\text { POLTCS }=\text { Vote } \\
\text { margin between parties }\end{array}$ & $\begin{array}{l}\text { POLTCS = Vote share } \\
\text { of ruling party }\end{array}$ & $\begin{array}{l}\text { POLTCS = Ruling party } \\
\text { won dummy }\end{array}$ \\
\hline $\begin{array}{l}\text { Population in } 2004 \\
(100,000 s)\end{array}$ & $\begin{array}{c}0.029 \\
(0.021)\end{array}$ & $\begin{array}{c}0.029 \\
(0.021)\end{array}$ & $\begin{array}{c}0.025 \\
(0.021)\end{array}$ \\
\hline Area in $2004\left(1000 \mathrm{~s}\right.$ of $\left.\mathrm{km}^{2}\right)$ & $\begin{array}{c}0.063 * * * \\
(0.019)\end{array}$ & $\begin{array}{c}0.065^{* * * *} \\
(0.019)\end{array}$ & $\begin{array}{c}0.069 * * * \\
(0.020)\end{array}$ \\
\hline $\begin{array}{l}\text { POLTCS in } 2000 \\
\text { presidential elections }\end{array}$ & $\begin{array}{c}0.001 \\
(0.002)\end{array}$ & $\begin{array}{c}0.005 \\
(0.005)\end{array}$ & $\begin{array}{c}0.108 \\
(0.097)\end{array}$ \\
\hline $\begin{array}{l}\text { POLTCS in } 1996 \\
\text { presidential elections }\end{array}$ & $\begin{array}{l}-0.002 \\
(0.003)\end{array}$ & $\begin{array}{l}-0.005 \\
(0.005)\end{array}$ & $\begin{array}{l}-0.099 \\
(0.097)\end{array}$ \\
\hline Observations & 110 & 110 & 110 \\
\hline & $\begin{array}{c}\text { POLTCS }=\text { Vote } \\
\text { margin between parties }\end{array}$ & $\begin{array}{l}\text { POLTCS = Vote share } \\
\text { of ruling party }\end{array}$ & $\begin{array}{c}\text { POLTCS = Proportion of } \\
\text { parliamentary seats won by } \\
\text { ruling party }\end{array}$ \\
\hline $\begin{array}{l}\text { Population in } 2004 \\
(100,000 \mathrm{~s})\end{array}$ & 0.029 & 0.025 & 0.024 \\
\hline & $(0.021)$ & $(0.021)$ & $(0.021)$ \\
\hline Area in $2004\left(1000 \mathrm{~s}\right.$ of $\left.\mathrm{km}^{2}\right)$ & $\begin{array}{c}0.065 * * * \\
(0.019)\end{array}$ & $\begin{array}{c}0.072 * * * \\
(0.020)\end{array}$ & $\begin{array}{c}0.072 * * * \\
(0.020)\end{array}$ \\
\hline $\begin{array}{l}\text { POLTCS in } 2000 \\
\text { Parliamentary elections }\end{array}$ & $\begin{array}{c}0.001 \\
(0.002)\end{array}$ & $\begin{array}{c}0.003 \\
(0.004)\end{array}$ & $\begin{array}{c}0.101 \\
(0.135)\end{array}$ \\
\hline $\begin{array}{l}\text { POLTCS in } 1996 \\
\text { Parliamentary elections }\end{array}$ & $\begin{array}{c}0.000 \\
(0.002)\end{array}$ & $\begin{array}{l}-0.001 \\
(0.004)\end{array}$ & $\begin{array}{l}-0.009 \\
(0.143)\end{array}$ \\
\hline Observations & 110 & 110 & 110 \\
\hline
\end{tabular}

